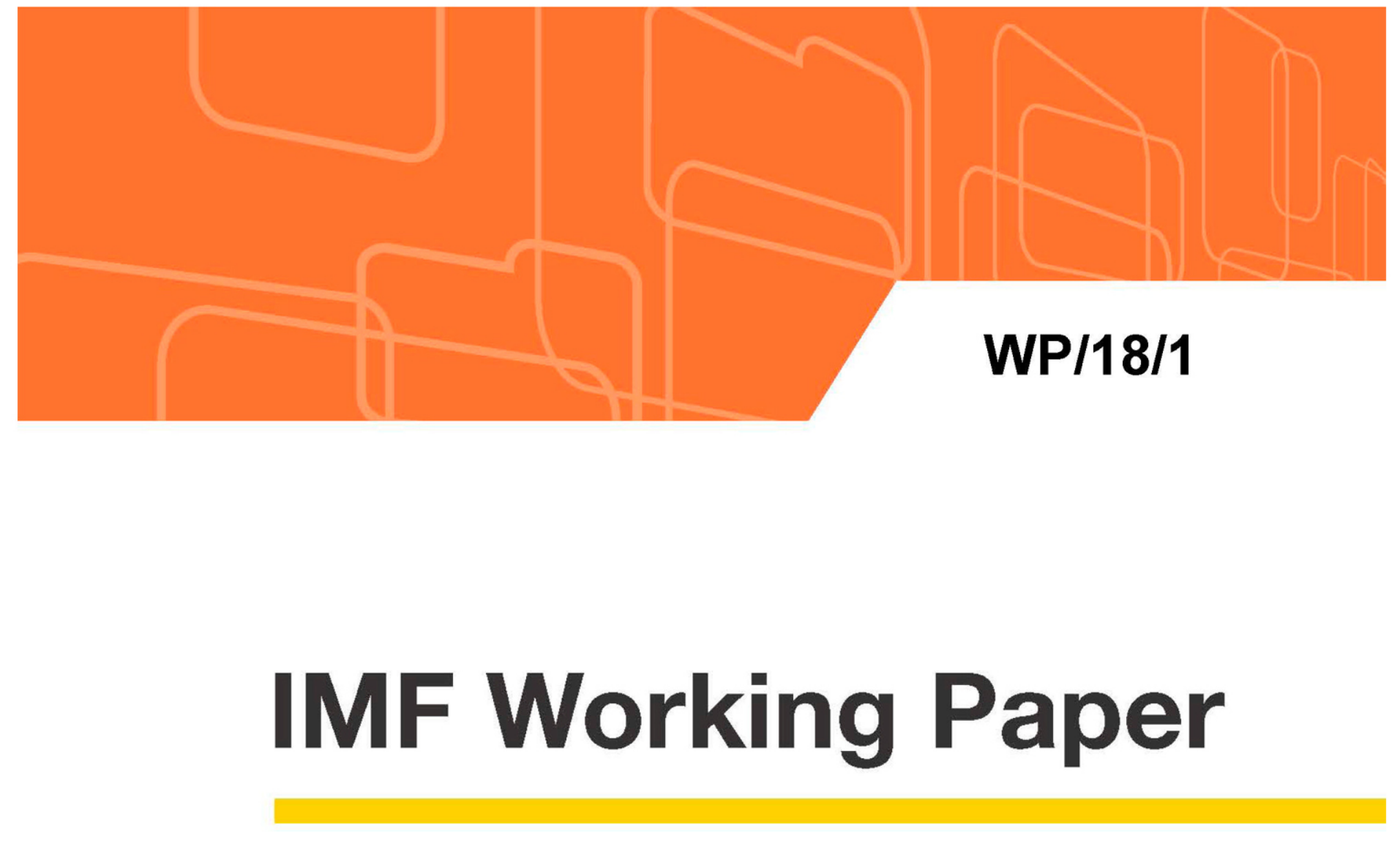

\title{
Optimism, Pessimism, and Short-Term Fluctuations
}

\author{
by Gabriel De Bella and Francisco Grigoli
}

IMF Working Papers describe research in progress by the author(s) and are published to elicit comments and to encourage debate. The views expressed in IMF Working Papers are those of the author(s) and do not necessarily represent the views of the IMF, its Executive Board, or IMF management.
I N
E R
N A T
N A L
M
- N E T A R Y
F U N D 


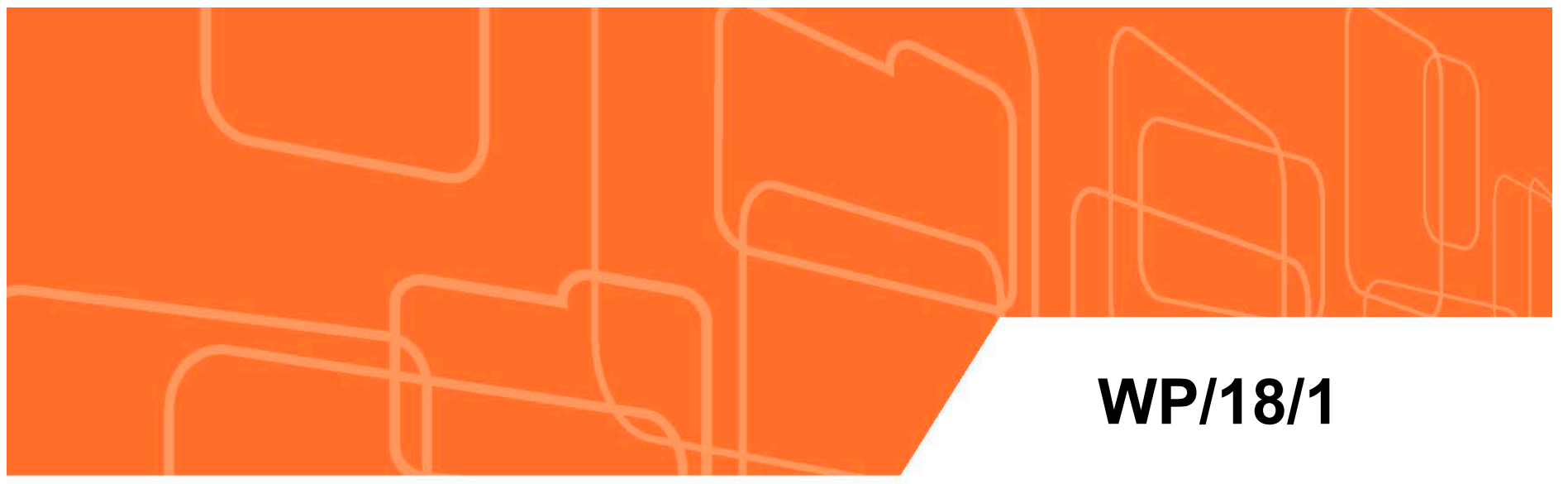

\title{
IMF Working Paper
}

\section{Optimism, Pessimism, and Short-Term Fluctuations}

\author{
by Gabriel De Bella and Francisco Grigoli
}

IMF Working Papers describe research in progress by the author(s) and are published to elicit comments and to encourage debate. The views expressed in IMF Working Papers are those of the author(s) and do not necessarily represent the views of the IMF, its Executive Board, or IMF management.
| N T E R N A T | O N A L
$M O N E T A R Y$
F U N D 


\title{
Optimism, Pessimism, and Short-Term Fluctuations*
}

\author{
Gabriel Di Bella ${ }^{\dagger} \quad$ Francesco Grigoli ${ }^{\ddagger}$
}

\begin{abstract}
Economic theory offers several explanations as to why shifting expectations about future economic activity affect current demand. Abstracting from whether changes in expectations originate from swings in beliefs or fundamentals, we test empirically whether more optimistic or pessimistic potential output forecasts trigger short-term fluctuations in private consumption and investment. Relying on a dataset of actual data and forecasts for 89 countries over the 1990-2022 period, we find that private economic agents learn from different sources of information about future potential output growth, and adjust their current demand accordingly over the two years following the shock in expectations. To provide a theoretical foundation to the empirical analysis, we also propose a simple Keynesian model that highlights the role of expectations about long-term output in determining short-term economic activity.
\end{abstract}

Keywords: Animal spirits, expectations, fluctuations, optimism, pessimism, self-fulfilling.

JEL Codes: E12, E32, E70.

*The views expressed in this Working Paper are those of the authors and do not necessarily represent those of the IMF or IMF policy. Working Papers describe research in progress by the authors and are published to elicit comments and to encourage debate. We thank, without implicating, Gianluca Benigno, Oya Celasun, Alfredo Cuevas, Jean-Paul L'Huillier, and Francisco Ramírez for their comments and suggestions.

${ }^{\dagger}$ International Monetary Fund, European Department, gdibella@imf.org.

${ }^{\ddagger}$ International Monetary Fund, Research Department, fgrigoli@imf.org. 


\section{Contents}

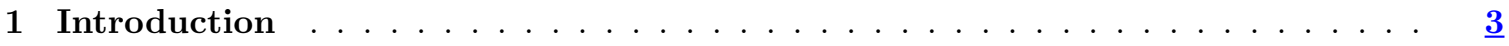

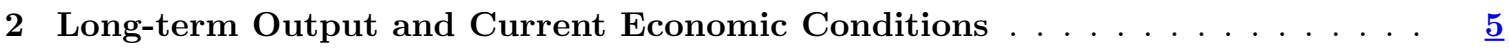

2.1 A Simple Keynesian Model: The Setup . . . . . . . . . . . . . . . $\underline{5}$

2.2 Expectations about Long-Term Output . . . . . . . . . . . . . . . . . $\underline{10}$

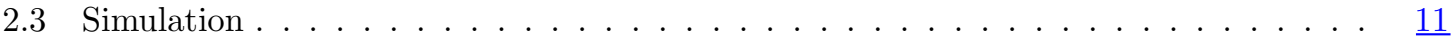

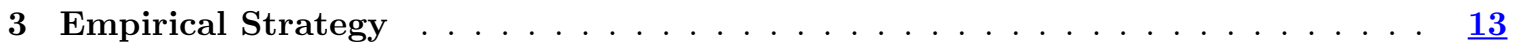

3.1 Data . . . . . . . . . . . . . . . . . . . . 13

3.2 Empirical Model . . . . . . . . . . . . . . . . . . . . $\underline{13}$

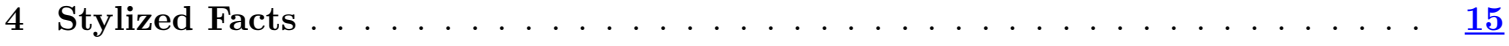

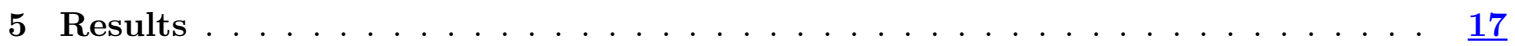

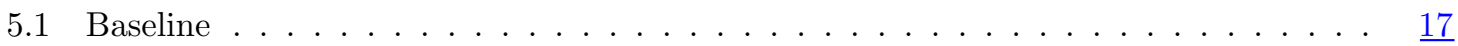

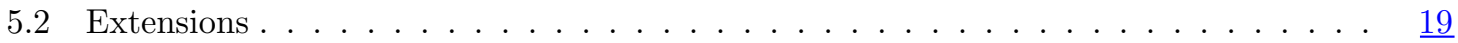

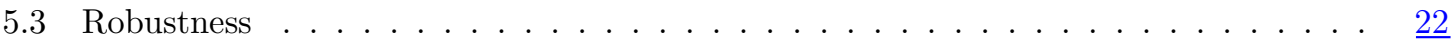

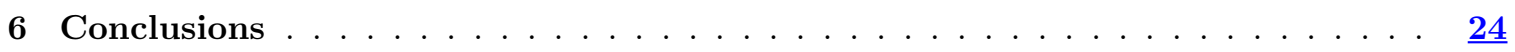

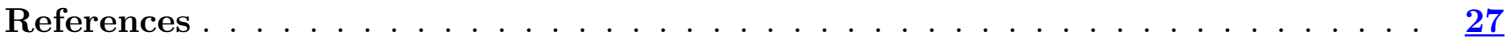

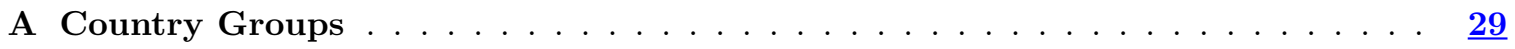

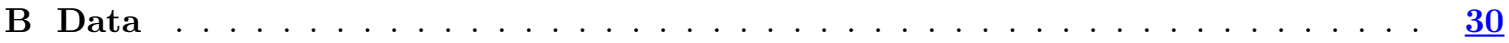

\section{List of Figures}

1. Page

1 Expected Long-Term Growth and Short-Term Economic Performance . . . . . . . $\underline{12}$

2 Revisions in Potential Output Growth Forecasts (Percent) . . . . . . . . . . . . . $\underline{16}$

3 Revisions in Potential Output Growth Forecast Before and After the GFC (Percent) $\underline{16}$

4 Revisions in Potential Output Growth Forecasts and Consumption and Investment Forecast Error (Percent) . . . . . . . . . . . . . . . . . . $\underline{19}$

5 Responses to a One pp Upward Revision in the Potential Output Growth Forecast

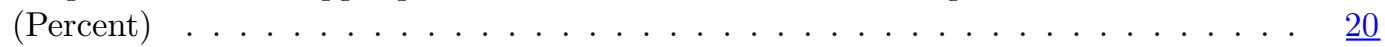

\section{List of Tables}

\begin{tabular}{|c|c|c|}
\hline & & Page \\
\hline 1 & Numerical Example . . . . . . . . . . . . . . . . . . . . . . . . . & . $\underline{12}$ \\
\hline 2 & Summary Statistics of Revisions to Potential Output Growth Forecasts (Percent) & $\underline{17}$ \\
\hline 3 & 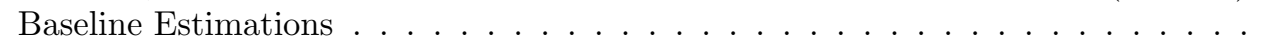 & $\underline{18}$ \\
\hline 4 & Interactions . . . . . & $\underline{21}$ \\
\hline 5 & Contr & $\underline{23}$ \\
\hline 6 & ness Chec & $\underline{24}$ \\
\hline$\gamma$ & Alternative Estimators & $\underline{25}$ \\
\hline & Data Sources ..... & \\
\hline
\end{tabular}




\section{Introduction}

The notion that changes in expectations about future economic activity affect current aggregate demand has a long tradition in macroeconomics. The vast literature about the impact of confidence on economic activity includes: (i) the view arguing that "animal spirits" (and "sunspots") eventually lead to busts as they are not supported by fundamentals (Cass and Shell, 1983; Akerlof and Shiller, 2010; De Grauwe and Ji, 2016); ${ }^{1}$ (ii) the view for which the same waves of optimism or pessimism associated with "animal spirits" do not necessarily lead to busts, rather they lead to self-fulfilling changes in fundamentals (Acharya et al., 2017; Benhabib et al., 2016), as changes in expectations of some agents trigger the actions of rational agents exhibiting strategic complementarities (Weil, 1989; Cooper and John, 1988); and (iii) a view generally referred to as "news-driven business cycles", which posits that agents become optimistic or pessimistic based on the (imperfect or noisy) information they gather about future developments. If the information is correct the boom lasts, but if it is incorrect or agents are overly optimistic, a bust would occur (Cochrane, 1994; Beaudry and Portier, 2004; Beaudry and Portier, 2006; Lorenzoni, 2009; Jaimovich and Rebelo, 2009, Beaudry et al., 2011; Schmitt-Grohé and Uribe, 2012; Blanchard et al., 2013). ${ }^{2}$

Regardless of whether changes in expectations about future economic conditions are caused by swings in beliefs or fundamentals, there is a broad theoretical consensus that they do affect current business activity. This is because consumers react to changes in their permanent income by smoothing consumption inter-temporally in line with the permanent income hypothesis (Friedman, 1957; Hall, 1978). Current economic booms or busts could then occur without actual technology advances or regresses (Sims, 2009). In other words, they could happen either because revisions in long-term growth predicated on fundamentals, or just because agents become more or less optimistic about the future. In this sense, Blanchard et al. (2017) argues that persistently low real GDP growth in the United States in the aftermath of the Global Financial Crisis (GFC) can, at least in part, be attributed to systematic downgrades to future potential output growth, giving rise to a strong positive correlation between revisions in potential output growth forecasts and current consumption and investment.

In this paper, we empirically test whether private economic agents expecting higher (lower) future potential output growth decide to consume and invest more (less) today relying on data revisions. Differently from other papers in the literature focusing only on one country, we rely on a panel data set of actual data and forecasts for 89 countries over the 1990-2022 period. Also, we study dynamics and selected non-linearities of expectation shocks. We provide the framework for the empirical analysis by proposing a simple Keynesian model showing that changes in expected longterm income have short-term effects in the direction of the change in expectations. Concretely, if agents expect long-term output growth to be high (low), short-term consumption, investment, and output in the short-term increase (fall), and unemployment falls (increases). In turn, increases (decreases) in consumption and investment today reinforce the expected decrease in long-term output, giving rise to a self-fulfilling mechanism. Broadly in line with the empirics, we assume that expectations are formed $\grave{a}$ la Banerjee (1992), so that changes in forecasts may either reflect a change in fundamentals or herding in the formation of expectations, in a process that could be

\footnotetext{
${ }^{1}$ Drawing on the behavioral economics literature, with "animal spirits" we refer to waves of optimism or pessimism (or more generally beliefs) that enact behaviors which fall outside what is normally understood as rational. This definition is somewhat more general than the original definition of Keynes (1936): "[...]a spontaneous urge to action rather than inaction, and not as the outcome of a weighted average of quantitative benefits multiplied by quantitative probabilities".

${ }^{2}$ See Beaudry and Portier (2014) for a review of the literature on "news-driven business cycles" theory and evidence.
} 
loosely assimilated to "animal spirits". ${ }^{3}$

This study belongs to a vast literature - largely focused on the United States - that employs a variety of approaches to identify expectation shocks and test their impact on current economic activity. Beaudry and Portier (2006), Beaudry and Lucke (2010), and Beaudry et al. (2011), for example, estimate reduced form VARs for the United States using stock price innovations orthogonal to total factor productivity (TFP) as a measure of news shocks, and short- and long-run restrictions to allow for a long-run effect on TFP. These papers generally report a large and positive effect of news on economic activity. Matsusaka and Sbordone (1995) also estimate a reduced form VAR, relying on consumer confidence data as a proxy of expectations and an indicator of economic activity for the United States. They find that expectations Granger-cause future output even after controlling for a set of macroeconomic variables. ${ }^{4}$ Chauvet and Guo (2003) estimate a similar VAR (with both consumer confidence data and a business sentiment indicator) allowing for different responses of economic agents depending on the stage of the business cycle. They find that shocks to expectations played a significant role during recession episodes in the United States. Barsky and Sims (2012) use a similar reduced form VAR and focus on disentangling "news shocks" and "animal spirits shocks". As the effects of these shocks are mostly permanent, they conclude that news shocks account for most of the variation in measured confidence.

The major drawback of the reduced form VAR is that the estimated coefficients capture only the effect of past shocks on current output. In contrast, Choy et al. (2006) estimate a structural VAR and find that expectation shocks unrelated to fundamentals are not a significant source of output fluctuations. The identification scheme assumes no contemporaneous effects from expectations to macroeconomic variables, based on the fact that forecasts are published at the end of each quarter, which is after consumption and investment decisions are taken. This approach, however, is questionable as economic agents also access information about the economy that is not statistically observed. If this information is unbiased, it reflects current macroeconomic variables, regardless of whether the realizations have been announced. Also, given that surveys are conducted during the quarter, expectations can affect macroeconomic variables in the same period. Grisse (2009) estimates a structural VAR using data on business conditions for Germany. Differently from most of the papers in the literature, the identification scheme relies on the heteroskedasticity in the data. ${ }^{5}$ His results suggest that expectation shocks about business conditions have a causal effect on industrial production.

Our approach is closer in spirit to the literature that departs from VAR specifications. Oh and Waldman (1990) and Oh and Waldman (2005) rely on revisions of leading economic indicators for the United States and find that announcements of a mistakenly booming economy have a positive effect on economic activity, supporting the self-fulfilling hypothesis. Our empirical strategy follows Blanchard et al. (2017), which use revisions to analyze the role of pessimism about future potential output growth in determining current consumption and investment in the United States. Given that potential output is a structural measure and therefore unlikely to determine current fluctuations, they argue that its revisions far into the future have a causal effect on current fluctuations in consumption and investment. ${ }^{6}$ They find that there is a strong positive correlation

\footnotetext{
${ }^{3}$ For instance, if herding results in a lower probability of the bad state of the world than the fundamental one, there there is an optimistic equilibrium, with "animal spirits" working to increase current consumption, investment, and output.

${ }^{4}$ Controlling for macroeconomic variables is generally thought as a way to derive expectation shocks orthogonal to fundamentals.

${ }^{5}$ See Rigobon (2003) for details about the identification through heteroskedasticity.

${ }^{6}$ While this is conceptually valid, effectively isolating exogenous shocks to long-term potential output is a daunting task as analysts may (incorrectly) revise potential output forecasts on the basis of short-term cyclical fluctuations. As noted by Blanchard et al. (2017), however, there is no other clear potential instrument. An alternative - employed in the empirical analysis - is to use potential output forecasts from other sources.
} 
between revisions in potential output growth forecasts and current consumption and investment.

Our results for a large panel of countries are supportive of the notion for which changes in expectations about future income cause short-term fluctuations. Specifically, we find that private economic agents learn from different sources of information about future potential output growth and adjust consumption and investment accordingly over the two years following the shock in expectations. For the average country with a share of private consumption (investment) to GDP of 65 (16) percent, a 0.1 percentage point ( $\mathrm{pp}$ ) upward revision to potential output growth forecast would bring about an acceleration in GDP growth in the range of 0.09 to 0.16 (0.06 to 0.11 ) percent. We also find that despite changes in expectations became more frequent, negatively skewed, and volatile in the aftermath of the global financial crisis (GFC), the estimated effects are not different with respect to the period preceding the GFC. Similarly, pessimistic and optimistic expectations do not present a differential impact on private consumption nor private investment, and large changes in expectations induce proportional changes in demand.

The rest of the paper is organized as follows. Section 2 presents a theoretical model motivating the empirical analysis. Section 3 outlines the empirical strategy. Section 4 examines the statistical properties of the expectations measure and its relationship with private consumption and investment. Section 5 discusses the econometric results, some extensions, and the robustness. Section 6 concludes.

\section{Long-term Output and Current Economic Conditions}

\subsection{A Simple Keynesian Model: The Setup}

We propose a simple Keynesian model showing that revisions in expected future income affect short-term equilibria. The model assigns a key role to money hoarding, as money hoarded subtracts from aggregate demand, thereby decreasing the marginal propensity to spend (MPS). ${ }^{7}$ This is not in any way original. For instance, at the beginning of the XVIII century John Law explained that economic slumps occur when "subjects [...] hoard up those signs of transmission as a real treasure, being induced to it by some motive of fear or distrust"; Law appears to have even referred to the self-fulling nature of a negative change in expectations about future output when he expressed that "I always call blind [...] because it stops a circulation that puts a State to a loss, and which is more likely than anything else to bring that poverty which they fear, both upon others and to themselves". A similar view was held by Thomas Joplin (a merchant and economic pamphleteer), who in the early XIX century explained that " $[\mathrm{A}]$ demand for money in ordinary times, and a demand for it in periods of panic [...] are diametrically different. The one demand is for money to put into circulation; the other for money to be taken out of it". ${ }^{8}$ In the same vein, Keynes (1936) questioned the validity of Say's law - that supply creates its own demand - in a monetary economy, because people can hoard money instead of purchasing goods, and this is indeed what people would do when prospects about future income deteriorate, resulting in a de-

\footnotetext{
${ }^{7}$ Although the model does not include banks, money hoarding can be assimilated to excess reserves by the banking system and unused demand deposits and cash in hand by non-financial economic agents. Increases in money hoarding in this sense should result, ex-post, in less credit (and deposits) and a lower money multiplier, which in turn would be the counterpart of a lower volume of economic transactions, given a price level.

${ }^{8}$ The references to Law's and Joplin's writings are from Martin (2015). He ascribes to the interpretation of the role of money as credit. He refers to two different historical traditions on the role of money. One tradition associates money with credit, while the other (in which he includes most classical economists) associates it with a commodity.
} 
crease of effective demand and MPS.

Our model describes a monetary economy in which fiat money plays the role of unit of account, has fixed nominal value, and is accepted as a mean of payment for goods and factor services. Given that money is readily accepted, it can be hoarded as a hedge against uncertain future conditions. In the model, only money for hoarding is modeled, while money used in transactions is assumed to "circulate". ${ }^{9}$ This means that money in circulation is assumed to be used for transactions (i.e., to pay for factors of production or goods), but when money is hoarded, it is excluded from circulation.

We assume that the economy is closed and that it is populated by a few economic forecasters, and many workers and entrepreneurs. ${ }^{10}$ Perfect competition is prevalent in goods and factor markets, and thus, neither individual workers nor entrepreneurs can affect market outcomes. There are three periods: period 0 , in which the economic forecasters receive signals of different quality in sequence and make forecasts; period 1 (interchangeably referred to as short-term in throughout the paper); and period 2 (or long-term). All economic transactions occur in periods 1 and 2, taking as given the forecasts produced in period $0 .{ }^{11}$

Both workers and entrepreneurs have identical utility functions over present and future consumption. Workers supply a constant amount of labor and receive a wage for their services. In the short term, they decide how to allocate their labor income between consumption and money hoarding, while in the future they use labor income plus any hoarded money balances (in real terms) to consume. ${ }^{12}$ Entrepreneurs maximize profits in the short term, demanding labor and using a fixed (given) capital stock. They allocate short-term profits among consumption, investment, and money hoarding. Investment in the short term determines the economy's capital stock in the long term. In the long term, entrepreneurs' consumption is financed by the real rents on capital plus the real value of money hoarded in the short term.

We introduce nominal rigidities by assuming that nominal wages are fixed in the short term. Fixed short-term nominal wages will result in unemployment if effective demand is sufficiently low. ${ }^{13}$ Sticky short-term nominal wages are the only nominal rigidity in the model - other prices are fully flexible both in the short term and in the long term.

The long-term real return to capital depends on total factor productivity (TFP), which is assumed to be stochastic. There exist two states of the world, good and bad. In the bad state of the world (which occurs with probability $0<\pi^{S}<1$ ), TFP growth rate is lower than in the good state of the world. Workers and entrepreneurs do not have private information about the probability of the bad state of the world. To account for that probability, they use a consensus forecast (assumed to be the same for all agents), which ensures the model's internal consistency.

\footnotetext{
${ }^{9}$ In the post-Keynesian tradition, money is seen as something that is created, circulates, and is destroyed within a single period (Godley and Lavoie, 2007).

${ }^{10}$ By assuming that the economy is closed, we impose that there are no transactions (financial or real) with the rest of the world.

${ }^{11}$ In a closed economy hoarding is not possible with bonds. Bonds are simultaneously a financial asset for some agents and a financial liability for agents on the other side of the transaction. Thus, in net terms, the amount of bonds in a closed economy is equal to zero in equilibrium. In contrast, money can be hoarded in the aggregate, as agents can hoard in equilibrium a positive amount of money.

${ }^{12}$ The (quite realistic) assumption about heterogeneous budget constraints for different agents (i.e., workers and entrepreneurs) tightens the link between economic uncertainty and money hoarding and investment. If the representative agent were both worker and entrepreneur, the incentives to invest would be related to not only the expected marginal productivity of capital, but also to the expected marginal productivity of labor.

${ }^{13}$ The literature assumes short-term nominal frictions resulting from imperfect competition in the goods market (Benigno, 2015) or from both imperfect competition in the goods and labor markets (Blanchard and Kiyotaki, 1987).
} 
Given a consensus forecast, the representative consumer (either worker or entrepreneur) maximizes the following utility function:

$$
\ln \left(c_{1}^{j}\right)+\beta E \ln \left(c_{2}^{j}\right)
$$

where $j=W, F$ denotes either workers $(W)$ or entrepreneurs $(F), C_{1}^{j}$ represents short-term consumption and $C_{2}^{j}$ long-term consumption, $0<\beta \leq 1$ is the consumer's subjective time preference, and $E$ is the expectation operator.

Workers maximize their utility function subject to the following constraints:

$$
\begin{gathered}
P_{1} c_{1}^{W}=W_{1} L_{1}^{d}-M_{1}^{W, h} \\
P_{2} c_{2}^{W, i}=W_{2}^{i} L_{2}+M_{1}^{W, h} \\
c_{1}^{W} \geq 0, \quad M_{1}^{W, h} \geq 0
\end{gathered}
$$

where $i=L, H$ denotes either the bad state of the world $(L)$ or the good state of the world $(H)$, $P_{t}$ represents the price level, $W_{t}$ denotes nominal wages, $L_{t}$ is labor demand, and $M_{1}^{j, h}$ is money hoarding. Labor income in the short term depends on the exogenous level of money wages and on labor demand (and thus the supra-index $d$ ). If the (endogenously determined) level of short-term prices is too low, labor demand may be lower than the (fixed) supply $\left(L_{1}^{d} \leq \bar{L}>0\right.$ ), and thus result in short-term unemployment. ${ }^{14}$

Entrepreneurs maximize their utility function subject to the following constraints:

$$
\begin{gathered}
P_{1} c_{1}^{F}=\Pi_{1}-M_{1}^{F, h}-P_{1} K_{2} \\
P_{2} c_{2}^{F, i}=R_{2}^{i} K_{2}+M_{1}^{F, h} \\
c_{1}^{F} \geq 0, \quad K_{2} \geq 0, \quad M_{1}^{F, h} \geq 0
\end{gathered}
$$

where $\Pi_{1}$ denotes (nominal) short-term profits, and $R_{2}$ and $K_{2}$ represent the (stochastic) nominal return of investment and real investment, respectively. The profit maximization problem in the short term takes the capital stock as given:

$$
\Pi_{1} \equiv P_{1} \sigma y_{1}-W_{1} L_{1}^{d}
$$

\footnotetext{
${ }^{14}$ This is similar to the way Sargent (1987) (Chapter 2) presents the labor market in his version of the Keynesian model.
} 
where $0<\sigma \leq 1$ is the MPS. ${ }^{15}$ This problem is subject to the following constraints:

$$
\begin{gathered}
y_{1} \leq A_{1} K_{1}^{\alpha} L_{1}^{1-\alpha} \\
\Pi_{1} \geq 0
\end{gathered}
$$

where $y_{1}$ denotes short-term output, $K_{1}>0$ is the short-term (given) capital stock, $A_{1}>0$ is the exogenous neutral TFP in the short term, and $0<\alpha<0$ is the production function parameter. Importantly, short-term profit maximization takes the aggregate MPS as given. The short-term MPS is defined as:

$$
\sigma(\cdot) \equiv \frac{P_{1} y_{1}-M_{1}^{h}}{P_{1} y_{1}}=1-\frac{M_{1}^{h} / P_{1}}{y 1}
$$

The rationale to include the MPS in the short-term profit maximization is that entrepreneurs know that in an interior equilibrium (i.e., given a sufficiently high probability of the bad state of the world), money is hoarded. The counterpart of money hoarding is unsold production, which materializes in the accumulation of inventories. Short-term monetary profits are determined by the volume of effective sales for consumption and investment (i.e., by effective demand). Given that unsold production is costly, entrepreneurs try to anticipate the level of the aggregate MPS, which is of course determined by aggregate expectations about the bad state of the world. Put differently, entrepreneurs' monetary costs are linked to total output, but receive monetary income only for sales, which is always below output in an interior equilibrium.

In the long term, profit maximization features all factors of production as variable:

$$
\Pi_{2} \equiv P_{2} y_{2}^{i}-W_{2}^{i} L_{2}-R_{2}^{i} K_{2}
$$

and is subject to the following constraint:

$$
y_{2}^{i} \leq A_{2}^{i} K_{2}^{\alpha} L_{2}^{1-\alpha}
$$

where $0<A_{2}^{L}<A_{2}^{H}$. The level of prices in the short term results from a quantitative theory of money-type equation. The monetary authority determines the supply of money in period 1 , $M_{1}=\bar{M}>0$ (which could be interpreted as, e.g., discount window loans from the central bank), but money circulating in the economy is endogenous. Accordingly, the level of prices in the short term results from the interaction between exogenous money supply, endogenous money hoarding, and the level of output:

$$
\left(M_{1}-M_{1}^{h}\right)=P_{1} y_{1}
$$

\footnotetext{
${ }^{15}$ Note that in the short-term there should be two measures of profits. One is that described in equation 8 , while the other includes unsold inventories. We refrain from discussing how unsold inventories should be valued, and just value them at market prices.
} 
In the long term, the monetary authority conducts any operations necessary to ensure that inflation is aligned to a given inflation target $(\varphi)$, and monetary policy is assumed to be fully credible. Given these assumptions, the long-term price level is given by:

$$
P_{2}=P_{1}(1+\varphi)
$$

The short-term price level determines the short-term level of real wages. If the probability about the bad state of the world in the consensus forecast is high enough, positive aggregate money hoarding results in a lower short-term price level. Money hoarding reduces money in circulation (in a loose sense, it limits the volume of credit), and thus, it results in a lower short-term price level. A lower price level combined with sticky wages may result in unemployment.

In an equilibrium (i.e., for each consensus forecast about the bad state of the world), workers pick $c_{1}^{W}, c_{2}^{W, i}$, and $M_{1}^{W, h}$; entrepreneurs (as consumers) pick $c_{1}^{F}, c_{2}^{F, i}, M_{1}^{F, h}$, and $K_{2}$; and entrepreneurs (as profit maximizers) pick $y_{1}, L_{1}^{d}, y_{2}^{i}, K_{2}^{i, d}$, and $L_{2}^{i, d}$. Monetary policy and money hoarding determine $P_{1}$ and $P_{2}^{i}$; in the long term, clearing in the market for factors of production (i.e., $L_{2}^{i, d}=$ $\bar{L}>0$ and $K_{2}^{i, d}=K_{2}$ ) determine values for $R_{2}^{i}$ and $W_{2}^{i}$, while in the short term $W_{1}=\bar{W}>0$, $K_{1}=\bar{K}>0$, and $L_{1}^{d} \leq \bar{L}$. The budget constraints for workers and entrepreneurs and the first order conditions (FOCs) derived from the problems faced by consumers and entrepreneurs close the model.

In particular, the workers' FOC refers to the equalization of short-term marginal utility of consumption and expected long-term (discounted) marginal utility of consumption:

$$
\frac{1}{c_{1}^{W}}=\beta\left[\pi \frac{1}{c_{2}^{W, L}(1+\varphi)}+(1-\pi) \frac{1}{c_{2}^{W, H}(1+\varphi)}\right]
$$

The entrepreneurs' FOCs (as consumers) are two. The first one-like that of workers - equals short-term marginal utility of consumption to expected long-term (discounted) marginal utility of consumption:

$$
\frac{1}{c_{1}^{F}}=\beta\left[\pi \frac{R_{2}^{L}}{c_{2}^{F, L} P_{2}^{L}}+(1-\pi) \frac{R_{2}^{H}}{c_{2}^{F, H} P_{2}^{H}}\right]
$$

The second FOC equals the marginal rate of substitution of consumption among different states of the world in the long term to the odds ratio times the difference in expected returns of different assets (namely money and capital):

$$
\pi \frac{1}{c_{2}^{F, L}}\left(\frac{P_{1}}{P_{2}^{L}}-\frac{R_{2}^{L}}{P_{2}^{L}}\right)+(1-\pi) \frac{1}{c_{2}^{F, H}}\left(\frac{P_{1}}{P_{2}^{H}}-\frac{R_{2}^{H}}{P_{2}^{H}}\right)=0
$$

The entrepreneurs' FOC (as profit maximizers) in period 1 determines short-term output:

$$
y_{1}=A_{1} K_{1}^{\alpha}\left[\frac{P_{1}}{W_{1}}(1-\alpha)\left(c_{1}+K_{2}\right)\right]^{1-\alpha}
$$

\section{(C)International Monetary Fund. Not for Redistribution}


Note that short-term output depends (through the MPS) on effective demand, giving the model its Keynesian flavor. Short-term output determines labor demand as follows:

$$
L_{1}^{d}=\left[\frac{y_{1}}{A_{1} K_{1}^{\alpha}}\right]^{\frac{1}{1-\alpha}}
$$

The entrepreneurs' FOC (as profit maximizers) in period 2 determine their long-term demand of labor and capital, given factor prices and TFP in different states of the world:

$$
\begin{gathered}
P_{2}^{i}(1-\alpha) A_{2}^{i} K_{2}^{i, d^{\alpha}} L_{2}^{i, d^{-\alpha}}=W_{2}^{i} \\
P_{2}^{i} \alpha A_{2}^{i} K_{2}^{i, d^{\alpha-1}} L_{2}^{i, d^{1-\alpha}}=R_{2}^{i}
\end{gathered}
$$

\subsection{Expectations about Long-Term Output}

The model assumes that the consensus forecast used by economic agents is produced by $N$ economic forecasters before other economic transactions take place. This assumption is somewhat artificial, but instrumental to provide a more straightforward connection with the empirical analysis. Forecasts are produced according to the game of incomplete information in Banerjee (1992). In what follows, we employ the same game structure but we deviate from it with respect to the interpretation of the results.

In period 0 , the (structural or fundamental) probability of the bad of the state of the world, $\pi^{S}$, is unknown, but falls within $0<\underline{\pi} \leq \pi^{S} \leq \bar{\pi}<1$. Economic forecasters are divided between those who receive a signal and those who do not receive any signal. Those who receive a signal learn the correct value of $\pi^{S}$ with probability $0<\psi<1$, and otherwise receive a wrong signal. The probability distribution among signals is uniform, and since the range above is continuous, the probability of any given signal within the range is zero. If a forecaster guesses the correct probability of the bad state of the world, she receives compensation $\xi>0$; in all other cases, she receives an equal, strictly positive, but lower compensation than if she was right. The aggregate cost of compensating the forecasters, $\Gamma$, is in the range $0 \leq \Gamma \leq \xi N$. To simplify the model, it is assumed that $\xi N$ is negligible with respect to the size of the economy, and that the cost to compensate the forecasters is distributed proportionally among the population in a lump-sum fashion in period 2. These assumptions ensure that the impact of forecasters' activity is only limited to establishing the expectations about the bad state of the world that are used by the population. Forecasters make forecasts in sequence, and the turn of each forecaster to make her forecast is randomly assigned. A forecaster learns her type at the moment in which her turn comes, which is when she is able to observe the forecasts that were made before her turn. The structure of the game and Bayesian rationality are common knowledge. ${ }^{16}$

\footnotetext{
${ }^{16}$ Banerjee (1992) makes three additional assumptions that allow a given forecaster to decide between two options that are equally attractive. The first such assumption is that if the decision maker has no signal and everyone else before has chosen $(\underline{\pi}+\bar{\pi}) / 2$, she also chooses $(\underline{\pi}+\bar{\pi}) / 2$; the second assumption is that when forecasters are indifferent between following their own signal, and someone else's, they follow their own; and the third assumption is that when the forecaster is indifferent between following more than one of the previous forecasts, she chooses the forecast entailing the highest probability. Each forecaster chooses a strategy in the form of a decision rule that defines what forecast to choose given her type, the timing of her decision, and the history of forecasts until the moment she needs to made a forecast herself. Given the tie-breaker assumptions described above, this game
} 
This setup allows for multiple equilibria depending on the ordering and signals that economic forecasters receive, many of them being the result of herding around wrong values of the bad state of the world. The consensus forecast (i.e., the average across forecasters) may thus potentially reflect herding, which results from the specific way in which individual information is aggregated. Although there are many other ways in which the model could have accounted for uncertainty about the actual probability of the bad state of the world and the formation of expectations, the mechanisms featured here account for problems with aggregation of information and herding that appear common in the way agents form aggregate expectations about the future. Thus, if herding results in a lower (higher) probability of the bad state of the world than the fundamental one, then there is an optimistic (pessimistic) equilibrium, with "animal spirits" working to increase current consumption, investment, and income.

\subsection{Simulation}

We now proceed to assign arbitrary values to the parameters, and exogenous and predetermined variables in order to simulate the results of the model for alternative values of expected long-term output. Table 1 reports the values assigned to variables and parameters and presents a summary of the results. A consensus forecast consistent with a probability of the bad state of the world above the true probability could be interpreted as a "pessimistic" forecast, while a consensus forecast that is below the actual probability of the bad state of the world could be interpreted as "optimistic". Thus, the expectation of an increased probability of the bad state of the world, and the expectation of lower long-term output growth are broadly equivalent statements. Needless to say, in a pessimistic equilibrium, short-term output, consumption, and investment are lower than the levels that would be justified by fundamentals (and the converse for an optimistic equilibrium).

As shown in Figure 1, if the expectation about long-term growth deteriorates (i.e., people expect an increased probability of the bad state of the world), then money hoarding increases, the MPS and effective demand (both aggregate consumption and investment) fall and short-term unemployment increases. Conversely, improved expected future economic prospects reduce money hoarding, increases the MPS, effective demand, and output, and reduces unemployment. In other words, a change in the consensus forecast has an effect on short-term economic variables in the direction of the forecast change, no matter whether the change in the forecast reflects an actual change in the underlying (structural) probability of the bad state of the world. Lower expected future productivity decreases investment (reinforcing the negative effect on long-term output), and results in a decline in current output, further decreasing permanent income. A change in expectations is enough to affect output, consumption, investment, and unemployment.

has a unique Bayesian Nash equilibrium. In other words, the structure of this game is identical to that in Banerjee (1992), with the exception that the motivation and the value chosen in the first tie-break assumption change. The reason for changing the first-tie break value assumption is to ensure that if forecasters receive no signal, they produce a forecast about the bad state of the world that is in the center of the range. This, however, does not affect the solution and conclusions of the game. 
Table 1: Numerical Example

\begin{tabular}{|c|c|c|c|c|c|c|}
\hline \multicolumn{7}{|c|}{ Expectation about long-term output } \\
\hline$E\left(y_{2}\right)$ & 0.06 & 0.04 & 0.01 & -0.01 & -0.04 & -0.06 \\
\hline \multicolumn{7}{|c|}{ Selected endogenous variables } \\
\hline$y_{1}$ & 3.15 & 3.13 & 3.10 & 3.08 & 3.05 & 3.03 \\
\hline$\mu$ & 0.21 & 0.22 & 0.23 & 0.24 & 0.25 & 0.26 \\
\hline$M_{1}$ & 1.67 & 1.82 & 1.96 & 2.10 & 2.24 & 2.38 \\
\hline$\sigma$ & 0.91 & 0.90 & 0.89 & 0.88 & 0.88 & 0.87 \\
\hline$C_{1}$ & 2.31 & 2.27 & 2.23 & 2.19 & 2.16 & 2.13 \\
\hline$I_{1}$ & 0.56 & 0.55 & 0.54 & 0.53 & 0.51 & 0.50 \\
\hline \multicolumn{7}{|c|}{ Parameters } \\
\hline$\beta$ & 0.99 & 0.99 & 0.99 & 0.99 & 0.99 & 0.99 \\
\hline$\alpha$ & 0.30 & 0.30 & 0.30 & 0.30 & 0.30 & 0.30 \\
\hline \multicolumn{7}{|c|}{ Exogenous/predetermined variables } \\
\hline$M_{1}$ & 20.00 & 20.00 & 20.00 & 20.00 & 20.00 & 20.00 \\
\hline$\varphi$ & 0.02 & 0.02 & 0.02 & 0.02 & 0.02 & 0.02 \\
\hline$W_{1}$ & 3.30 & 3.30 & 3.30 & 3.30 & 3.30 & 3.30 \\
\hline$A_{1}$ & 1.30 & 1.30 & 1.30 & 1.30 & 1.30 & 1.30 \\
\hline$A_{2}^{L}$ & 0.40 & 0.40 & 0.40 & 0.40 & 0.40 & 0.40 \\
\hline$A_{2}^{H}$ & 2.10 & 2.10 & 2.10 & 2.10 & 2.10 & 2.10 \\
\hline$K_{1}$ & 1.00 & 1.00 & 1.00 & 1.00 & 1.00 & 1.00 \\
\hline$L^{S}$ & 4.50 & 4.50 & 4.50 & 4.50 & 4.50 & 4.50 \\
\hline \multicolumn{7}{|c|}{$\begin{array}{l}\text { Source: Authors' calculations. } \\
\text { Notes: } E\left(y_{2}\right) \text { refers to the expected growth rate of } \\
\text { long-term real output, } \mu \text { refers to the unemploy- } \\
\text { ment rate, and } I_{1} \text { refers to aggregate investment } \\
\text { (i.e., capital stock in period } 2 \text { ). }\end{array}$} \\
\hline
\end{tabular}

Figure 1: Expected Long-Term Growth and Short-Term Economic Performance
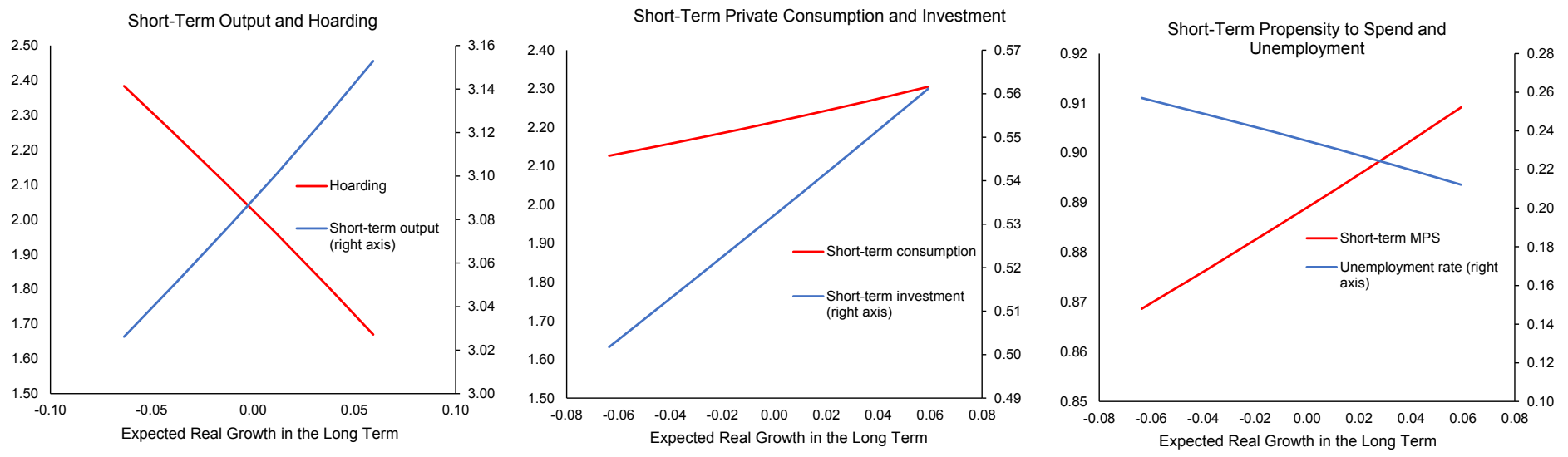

Source: Authors' calculations. 


\section{Empirical Strategy}

\subsection{Data}

We rely on data from the International Monetary Fund's (IMF) World Economic Outlook (WEO), released twice a year (in the spring and the fall). The WEO database consists of actual macroeconomic data and forecasts submitted by country teams and vetted by the IMF's Research Department for both internal and multilateral consistency. The Spring WEO was released in May up through 2001 and in April thereafter; the fall version is typically released in October, and occasionally in September. Starting in 1990, every vintage contains forecast for the next five years. Given the production lags, forecasts for the spring publication are performed during February or March. Given this timeline, in the Spring WEO data for the previous year are an estimate or forecast for some countries. The Fall WEO is based on final information, therefore we use fall vintages from 1990 to 2016.

\subsection{Empirical Model}

Our empirical framework is similar to the one employed by Blanchard et al. (2017). Our dependent variable is defined as the deviation of, alternatively, the observed real consumption growth, $c$, or real investment growth, $i$, from its previous year growth forecast. ${ }^{17}$ Thus, for year $t$ and country $j$, we calculate such deviations as:

$$
D_{j, t}^{c}=c_{j, t}-\left[\frac{E_{j, t-1}\left(C_{j, t}\right)}{E_{j, t-1}\left(C_{j, t-1}\right)}-1\right]=c_{j, t}-E_{j, t-1}\left(c_{j, t}\right)
$$

and

$$
D_{j, t}^{i}=i_{j, t}-\left[\frac{E_{j, t-1}\left(I_{j, t}\right)}{E_{j, t-1}\left(I_{j, t-1}\right)}-1\right]=i_{j, t}-E_{j, t-1}\left(i_{j, t}\right)
$$

where $C$ and $I$ are the levels of real consumption and real investment, respectively. Forecasts for consumption and investment must be as of a time in which the information to prepare the revised forecasts of potential real GDP growth is not available yet. In our case, we will use data of the Fall WEO of year $t-1$.

To construct the expectation measure about the economy $j$, we take the forecast available in the Fall WEO of year $t$ of potential real GDP growth, $y^{*}$, for year $t+(N-1)$ (with $N=5$ being the WEO forecast horizon), and denote it by $E_{j, t}\left(y_{j, t+(N-1)}\right)$. Then, we define the forecast revision as its difference with respect to the forecast published in the previous vintage of the Fall WEO (at time $t-1)$ for the same year $t+(N-1):^{18}$

$$
R_{j, t}^{N-1}=E_{j, t}\left(y_{j, t+(N-1)}\right)-E_{j, t-1}\left(y_{j, t+(N-1)}\right)
$$

Given that every Fall WEO contains forecasts for the next five years, we can generate up to four different variables depending on the forecasting horizon. However, with the objective of isolating

\footnotetext{
${ }^{17}$ Note that we take the observed value for $c$ and $i$ at time $t$ from the Fall WEO of time $t+1$, to rule out the possibility that the value reported is still an estimate.

${ }^{18}$ Note that to compute the forecast revision, we take the forecast for the second to last year of the forecast horizon $(t+(N-1))$ instead of the last year $(t+N)$ because that is available both for the Fall WEO at time $t$ and at time $t-1$.
} 
structural changes far into the future from cyclical movements, we select the farthest computable revision as our favorite measure.

The specification employed here assumes that households and corporations adjust consumption and investment based on two sources of information. In proportion $\alpha$, they learn about future potential output growth at the time of the Fall WEO publication of year $t$, hence adjusting consumption and investment over $t$. In proportion $(1-\alpha)$, they learn about future potential output growth from the same information used by the IMF to produce the forecasts, therefore adjusting their consumption and investment already in $t-1$.

Thus, similar to Blanchard et al. (2017), we specify the following reduced form equation for private consumption and private investment:

$$
D_{j, t}^{c, i}=\gamma+\beta\left[(1-\alpha) R_{j, t}^{N-1}+\alpha R_{j, t+1}^{N-1}\right]+\mu_{j}+\tau_{t}+\epsilon_{j, t}
$$

where $\gamma$ is a constant term, $\beta$ is an encompassing coefficient on the forecast revision term, $\mu_{j}$ and $\tau_{t}$ are the time- and country-fixed effects, and $\epsilon_{j, t}$ is a vector of residuals. To retrieve the value of $\alpha$, equation (26) can be rearranged as:

$$
D_{j, t}^{c, i}=\gamma+\alpha \beta\left(R_{j, t+1}^{N-1}-R_{j, t}^{N-1}\right)+\beta R_{t}^{N-1}+\mu_{j}+\tau_{t}+\epsilon_{j, t}
$$

where $\alpha=\alpha \beta / \beta$.

The possibility of reverse causality when estimating equation (27) deserves further discussion. As in Blanchard et al. (ibid.), we argue that unexpected cyclical movements in private consumption growth and private investment growth are unlikely to affect forecasts of potential output growth far into the future. If this true, we can then identify a causal relationship. One could argue that the use of statistical methods to compute the potential output could introduce a spurious correlation between the forecast error in private consumption and investment growth and the forecast revision of potential output growth. However, the review of the estimation method used by the IMF in De Resende (2014) notes:

"Survey evidence shows that in the Fund's medium-term forecasting the use of any particular individual forecasting method is much less universal than the use of judgmentunderstood as a set of information and knowledge, not necessarily quantitative in nature, that desk economists and mission chiefs accumulate about the countries on which they work."

Furthermore, as a robustness test, we use estimates of potential output from the OECD's Economic Outlook database, assuming that this breaks further the spurious link with private consumption and investment growth from the IMF's WEO database.

In order to retrieve the dynamics of the effect of a change in expectations about the potential output growth on consumption and investment, we construct impulse response functions employing the local projection method of Jordà (2005). Thus, we estimate $h$ sets of regressions of the form:

$$
D_{j, t+h}^{c, i}=\gamma^{h}+\alpha^{h} \beta^{h}\left(R_{j, t+1}^{N-1}-R_{j, t}^{N-1}\right)+\beta^{h} R_{j, t}^{N-1}+\mu_{j}^{h}+\tau_{t}^{h}+\epsilon_{j, t}^{h} \quad h=0,1,2, \ldots, s
$$

where $\alpha^{h}$ and $\beta^{h}$ describe the response of $D_{j, t+h}^{c, i}$ to the shock at horizon $h$. 
Different from Blanchard et al. (2017) that focus only on the United States, cross-country differences not captured by time- and country-fixed effects may play a role in determining the forecast error of private consumption and private investment growth. Thus, to check the robustness of the results to the inclusion of other covariates, we estimate:

$$
D_{j, t}^{c, i}=\gamma+\alpha \beta\left(R_{j, t+1}^{N-1}-R_{j, t}^{N-1}\right)+\beta R_{t}^{N-1}+\delta D_{j, t}^{x}+\psi S_{j, t}+\mu_{j}+\tau_{t}+\epsilon_{j, t}
$$

where $D_{j, t}^{x}$ is a vector of control variables $X_{j, t}$ expressed in terms of deviation with respect to their forecast, $S_{j, t}$ is another vector of control variables, and $\delta$ and $\psi$ are the relative coefficients. ${ }^{19}$

Some of the control variables may be co-determined with the dependent variables, with each affecting the other, which results in endogeneity. Thus, we estimate equation (27) using the System Generalized Method of Moments (S-GMM) estimator, which relies on a system of two simultaneous equations, one in levels (with lagged first differences as instruments) and the other in first differences (with lagged levels as instruments). ${ }^{20,} 21$

\section{Stylized Facts}

Figure 2 shows the distribution of the revisions in potential output growth forecasts. As shown in the left panel, the frequency distribution of the data (black bars) resembles a normal distribution (red line), but with leptokurtic features. The clustering around the mean is related to the high recurrence of small revisions, consistent with the idea that a structural measure of productive capacity should not change often and drastically. Interestingly, the distribution is slightly negative skewed, suggesting that pessimistic expectations were dominating optimistic ones over the sample period.

We now move to analyze how the distribution of revisions in potential output growth forecast changed over time. The right panel of Figure 2 presents a series of box plots that display some interesting aspects of expectations around the time of the GFC. While the average revision of potential output growth forecasts hovered around zero for the entire time period, in 2008 and 2009 it became negative. Moreover, starting in 2008 expectations became more dispersed, as indicated by the distant ends of the whiskers and more extreme values.

To dig deeper into the differences between the pre- and post-GFC period, we present the frequency distributions and the scatter plots for the periods 1991-2007 and 2008-16 in Figure 3. The left panel shows that negative revisions became more frequent in the aftermath of the GFC, suggesting that expectations were often revised downward. The right panel confirms this, but also shows that extreme values were both positive and negative, possibly reflecting policy reactions as well as the realization of a structural fall in output.

\footnotetext{
${ }^{19}$ Ideally, all variables should be expressed in terms of deviation with respect to their forecast. However, data availability forces to use the observed value for the variables in vector $S_{j, t}$.

${ }^{20}$ Besides the general assumptions of a Difference GMM estimation-idiosyncratic error serially uncorrelated and past values of the endogenous variables uncorrelated with the current error - the S-GMM estimator requires the additional identifying assumption that the instruments are exogenous to the country-fixed effects.

${ }^{21}$ We employ the asymptotically more efficient two-step S-GMM. The two-step variant presents estimates of the standard errors that tend to be severely downward biased (Arellano and Bond, 1991; Blundell and Bond, 1998). However, we implement the finite-sample correction of the two-step covariance matrix derived by Windmeijer (2005), which produces unbiased standard errors.
} 
Figure 2: Revisions in Potential Output Growth Forecasts

(Percent)
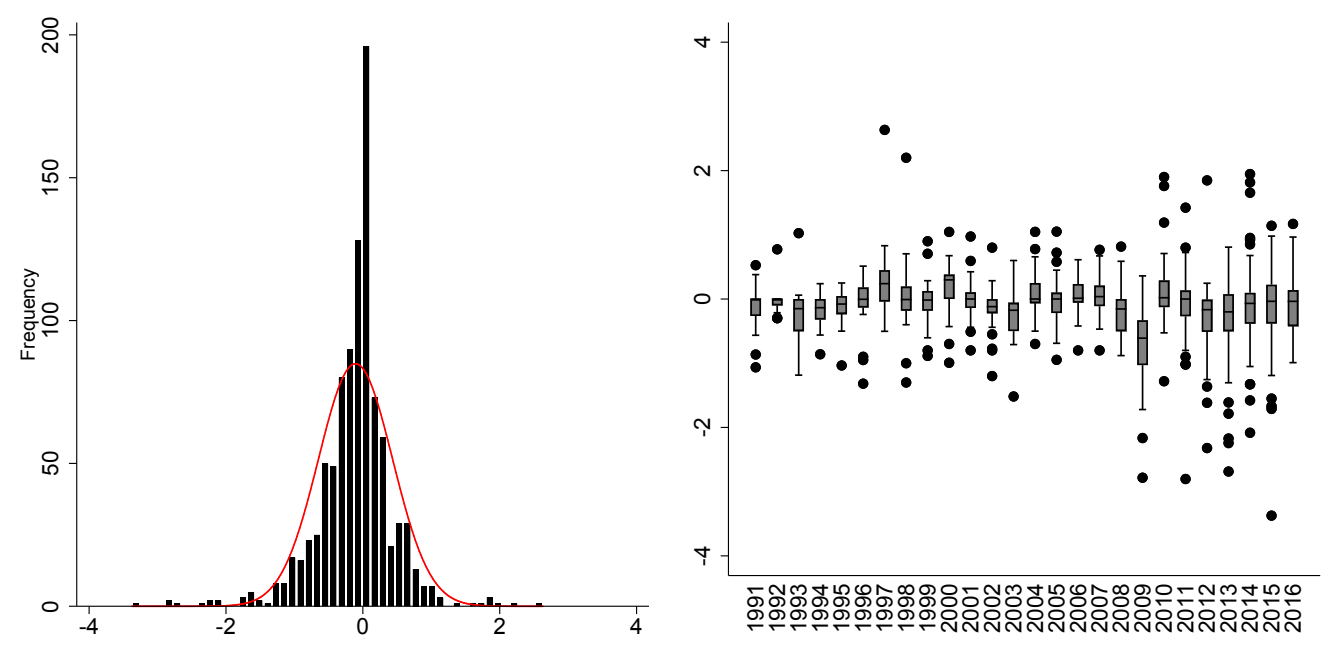

Source: Authors' calculations.

Notes: The panels exclude two outliers correpsonding to Portugal in 1991 and 1994.

Figure 3: Revisions in Potential Output Growth Forecast Before and After the GFC

(Percent)
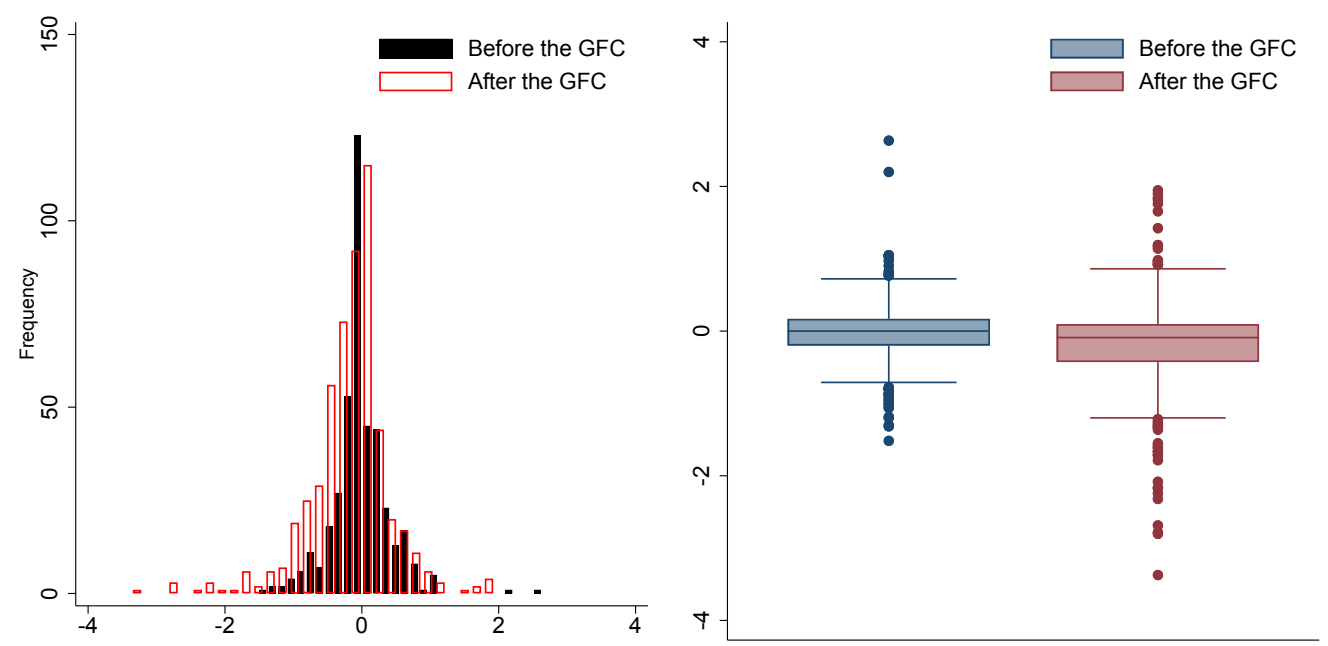

Source: Authors' calculations.

Notes: The panels exclude two outliers correpsonding to Portugal in 1991 and 1994.

Table 2 presents some summary statistics of the revisions to potential output growth forecasts, which highlight more specifically the heterogeneity across income levels, periods, and direction of the revisions. As already noted in Figure 2, the average revision across countries is negative (-0.11 percent), negatively skewed, and with a high concentration of values around the mean. However, Emerging Market and Developing Economies (EMDE), on average, suffered negative revisions of -0.17 percent, or two times larger than Advanced Economies (AE). ${ }^{22}$ Relative to AE, revisions in

\footnotetext{
${ }^{22}$ We adopt here the income group classification of the Fall WEO of 2016. See Appendix A for the list of countries in the sample.
} 
EMDE were more varied as suggested by the higher standard deviation. Consistent with the panels in Figure 3, the average revision before the GFC was very close to zero, but it became negative at -0.17 percent and more volatile starting in 2008 . Finally, there is no relevant difference in the average absolute value or volatility between positive and negative revisions. Overall, these stylized facts suggest that it is relevant to empirically test if households and corporations became more sensitive to changes in expectations following the GFC, and whether they are more responsive to pessimistic rather than optimistic expectations.

Table 2: Summary Statistics of Revisions to Potential Output Growth Forecasts (Percent)

\begin{tabular}{lcccccc}
\hline & Obs. & Mean & Median & Std. dev. & Skewness & Kurtosis \\
\hline Full sample & 960 & -0.11 & -0.04 & 0.54 & -0.63 & 8.44 \\
$\begin{array}{l}\text { Income groups } \\
\text { AE }\end{array}$ & & & & & & \\
$\quad$ EMDE & 242 & -0.08 & -0.02 & 0.45 & -0.27 & 8.37 \\
$\quad \begin{array}{l}\text { Periods } \\
\text { Before GFC }\end{array}$ & & -0.17 & -0.08 & 0.75 & -0.61 & 5.78 \\
$\quad$ After GFC & 512 & -0.02 & 0.00 & 0.42 & 0.64 & 8.90 \\
Direction & 548 & -0.17 & -0.09 & 0.61 & -0.77 & 7.20 \\
$\quad$ Pessimistic & & & & & & \\
$\quad$ Optimistic & 591 & -0.37 & -0.25 & 0.45 & -2.45 & 11.68 \\
\hline
\end{tabular}

Source: Authors' calculations.

Notes: The calculations exclude two outliers corresponding to Portugal in 1991 and 1994.

\section{Results}

We present here the results of the estimations. We start with a baseline parsimonious model. Then, we extend it to include other independent variables. Finally, we test its robustness.

\subsection{Baseline}

Similar to Blanchard et al. (2017), we start with a baseline specification for both real private consumption growth and real private investment growth. This includes both the revision of potential output growth forecasts and the difference between its value in $t+1$ and $t$, which allow to compute how much is learned at the time of the Fall WEO publication and how much at the time the same information is used by the IMF to produce its forecasts; country-fixed effects; and time-fixed effects. Table 3 reports the results of OLS estimations for the full sample (columns 1 and 2), AE (columns 3 and 4), and EMDE (columns 5 and 6).

The results show that both the revision of potential output growth forecasts and its time difference are significant across country groups and for both real private consumption and investment growth. The only exception is the coefficient on the time difference in the real private investment growth equation for EMDE, but this is likely due to a reduced number of observations. For the full sample, these factors explain about one fifth of the variation in consumption and investment growth.

In the estimations for the full sample, the coefficient $\alpha$-denoting how much agents learn about 
future potential output growth at the time of the Fall WEO publication of year $t$ - is not too far from 0.5 , suggesting that households and corporations learn about future potential output growth both at the time of the WEO publication and at the same time the IMF produces its forecasts. However, in the results for AE, $\alpha$ is substantially smaller than in the results for EMDE, suggesting that in the former (latter) economic agents learn mostly at the same time of the IMF (Fall WEO publication). This is consistent with the notion for which economic agents are more sophisticated in $\mathrm{AE}$ in that they have wider access to information about the potential output growth of the economy and a more refined ability to elaborate it than in EMDE. The coefficient for $\beta$ ranges between 1.9 and 2.5 in the private consumption specifications, and between 3.9 and 7.2 in the private investment specifications. This implies that a $0.1 \mathrm{pp}$ downward revision in the potential output growth forecast is associated with a 0.19 to 0.25 (0.39 to 0.72$)$ percent reduction in private consumption (investment) growth. For the average country with a share of private consumption (investment) to GDP of 65 (16) percent, this would bring about a reduction in GDP growth by 0.09 to 0.16 (0.06 to 0.11$)$ percent.

Table 3: Baseline Estimations

\begin{tabular}{|c|c|c|c|c|c|c|}
\hline & $\begin{array}{l}\text { Dep: real } \\
\text { PC } \\
\text { growth } \\
\text { forecast } \\
\text { error } \\
\text { Full } \\
\text { sample } \\
\end{array}$ & $\begin{array}{c}\text { Dep: real } \\
\text { PI } \\
\text { growth } \\
\text { forecast } \\
\text { error } \\
\text { Full } \\
\text { sample }\end{array}$ & $\begin{array}{l}\text { Dep: real } \\
\text { PC } \\
\text { growth } \\
\text { forecast } \\
\text { error } \\
\mathrm{AE}\end{array}$ & $\begin{array}{c}\text { Dep: real } \\
\text { PI } \\
\text { growth } \\
\text { forecast } \\
\text { error } \\
\text { AE }\end{array}$ & $\begin{array}{l}\text { Dep: real } \\
\text { PC } \\
\text { growth } \\
\text { forecast } \\
\text { error } \\
\text { EMDE }\end{array}$ & $\begin{array}{c}\text { Dep: real } \\
\text { PI } \\
\text { growth } \\
\text { forecast } \\
\text { error } \\
\text { EMDE }\end{array}$ \\
\hline$R_{t+1}^{4}-R_{t}^{4}$ & $\begin{array}{c}0.874^{* * *} \\
(0.239)\end{array}$ & $\begin{array}{c}2.288^{* * *} \\
(0.687)\end{array}$ & $\begin{array}{c}0.875^{* * *} \\
(0.253)\end{array}$ & $\begin{array}{c}2.550^{* * *} \\
(0.860)\end{array}$ & $\begin{array}{c}0.930^{* *} \\
(0.452)\end{array}$ & $\begin{array}{l}2.178^{*} \\
(1.182)\end{array}$ \\
\hline$R_{t}^{4}$ & $\begin{array}{c}1.872^{* * *} \\
(0.365)\end{array}$ & $\begin{array}{c}5.212^{* * *} * \\
(1.674)\end{array}$ & $\begin{array}{c}2.493^{* * *} \\
(0.440)\end{array}$ & $\begin{array}{c}7.234^{* * *} \\
(1.781)\end{array}$ & $\begin{array}{l}1.391^{* *} \\
(0.626)\end{array}$ & $\begin{array}{c}3.871 \\
(2.858)\end{array}$ \\
\hline Constant & $\begin{array}{c}-0.514^{*} \\
(0.281)\end{array}$ & $\begin{array}{l}-4.969^{*} \\
(2.527)\end{array}$ & $\begin{array}{l}-0.245 \\
(0.283)\end{array}$ & $\begin{array}{c}-5.249^{* *} \\
(2.535)\end{array}$ & $\begin{array}{l}-0.125 \\
(1.063)\end{array}$ & $\begin{array}{l}5.464^{*} \\
(3.186)\end{array}$ \\
\hline Observations & 782 & 566 & 598 & 396 & 184 & 170 \\
\hline$R^{2}$ & 0.199 & 0.187 & 0.332 & 0.274 & 0.082 & 0.124 \\
\hline Countries & 89 & 83 & 36 & 33 & 53 & 50 \\
\hline$\alpha$ & 0.467 & 0.439 & 0.351 & 0.353 & 0.669 & 0.563 \\
\hline$\beta$ & 1.872 & 5.212 & 2.493 & 7.234 & 1.391 & 3.871 \\
\hline
\end{tabular}

Figure 4 presents the scatter plots of the weighted average of the revisions to potential output growth forecasts in $t$ and $t+1$ against real private consumption and investment growth forecast error. Specifically, the measure of the horizontal axis is equal to $\left[(1-\alpha) R_{j, t}^{N-1}+\alpha R_{j, t+1}^{N-1}\right]$, where $\alpha$ takes the value in columns 1 and 2 of Table 3. The measures on the vertical axis are the ones described in equation (23) for the left panel and equation (24) for the right panel. Both panels depict a well-defined positive relationship, confirming that households and corporations increase demand to adjust to more optimistic expectations.

Figure 5 shows the impulse response functions derived by applying the local projections method, which allow to appreciate the dynamic effect of better expectations. The black line one period after the shock displays the $\beta$ coefficient of Table 3. Similarly, the red dot one period after the shock displays the $\alpha$ coefficient. ${ }^{23}$ The red lines define the band of possible values of the $\alpha$ coeffi-

\footnotetext{
${ }^{23}$ To avoid overlapping confidence intervals, we report the size of the $\alpha$ coefficient only when it turns out signifi-
} 
Figure 4: Revisions in Potential Output Growth Forecasts and Consumption and Investment Forecast Error

(Percent)
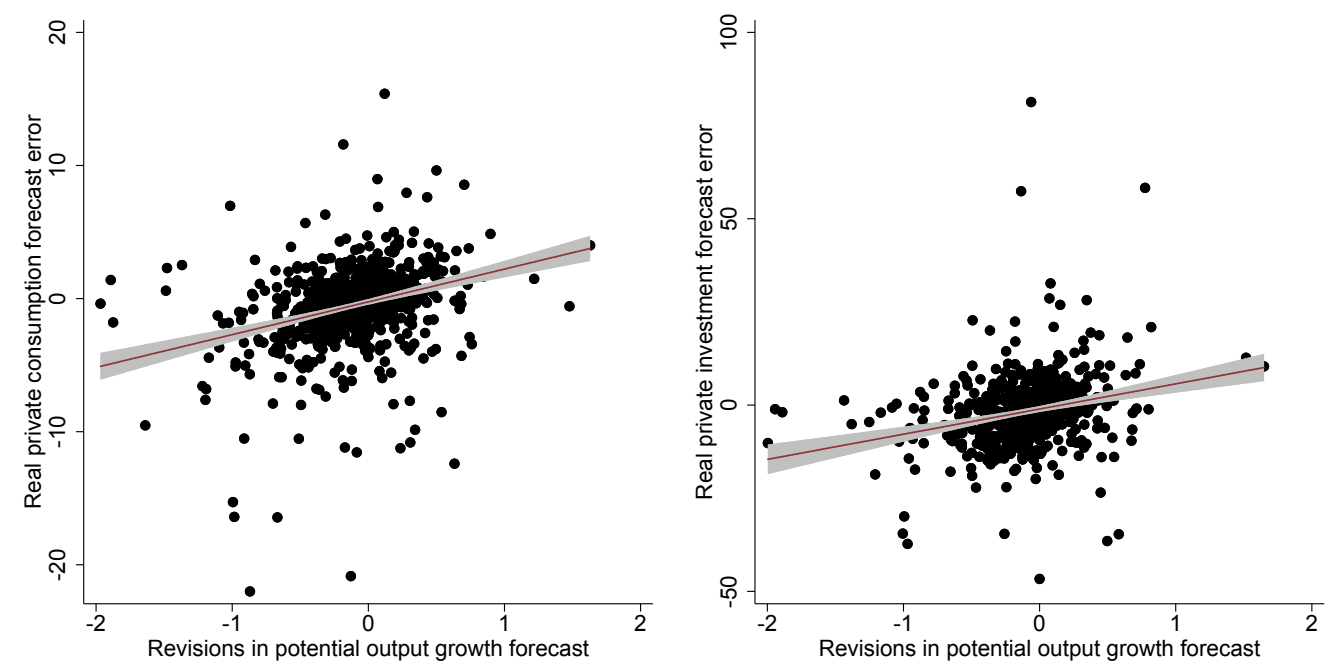

Source: Authors' calculations.

cient. In the case of real private consumption growth (first row of panels), the positive effect of an improvement in expectations phases out after two years for the full sample and AE, while it only lasts one year for EMDE. This also holds for the impact on private investment growth (second row of panels), with the exception of EMDE, for which the effect is not significant. The red dots provide information regarding the learning of economic agents over time. As expected, these red dots tend to approach one over time, consistent with the idea that as the time goes by, economic agents are increasingly informed by the WEO Fall publication. ${ }^{24}$

\subsection{Extensions}

One can think of a series of factors that could shape non-linearities in the relationship between expectations and consumption and investment. As we discussed in Section 4, the GFC came with a great deal of uncertainty that may have changed the sensibility of economic agents to an improvement or a worsening of expectations. Similarly, households and corporations may adjust asymmetrically to worse and better expectations. Lastly, large revisions in expectations may produce non-proportional effects on consumption and investment.

Table 4 tests for these possible non-linearities by adding interaction terms to the specification to be estimated. In columns 1 and 2, we interact our variables of interest with a dummy that takes value one after the GFC to test for differential effects since then. In columns 3 and 4 , we add an interacting dummy that takes value one when revisions to potential output growth forecasts are negative, hence testing if economic agents react differently to pessimistic expectations with respect to positive ones. Finally, in columns 5 and 6 , we add the expectations terms squared to proxy large revisions. For every column, we calculate $\alpha$ and $\beta$ with and without interaction terms.

cant.

${ }^{24}$ An $\alpha$ coefficient different from one two years after the shock implies that economic agents learn from the IMF official forecasts with a delay. 
Figure 5: Responses to a One pp Upward Revision in the Potential Output Growth Forecast

(Percent)
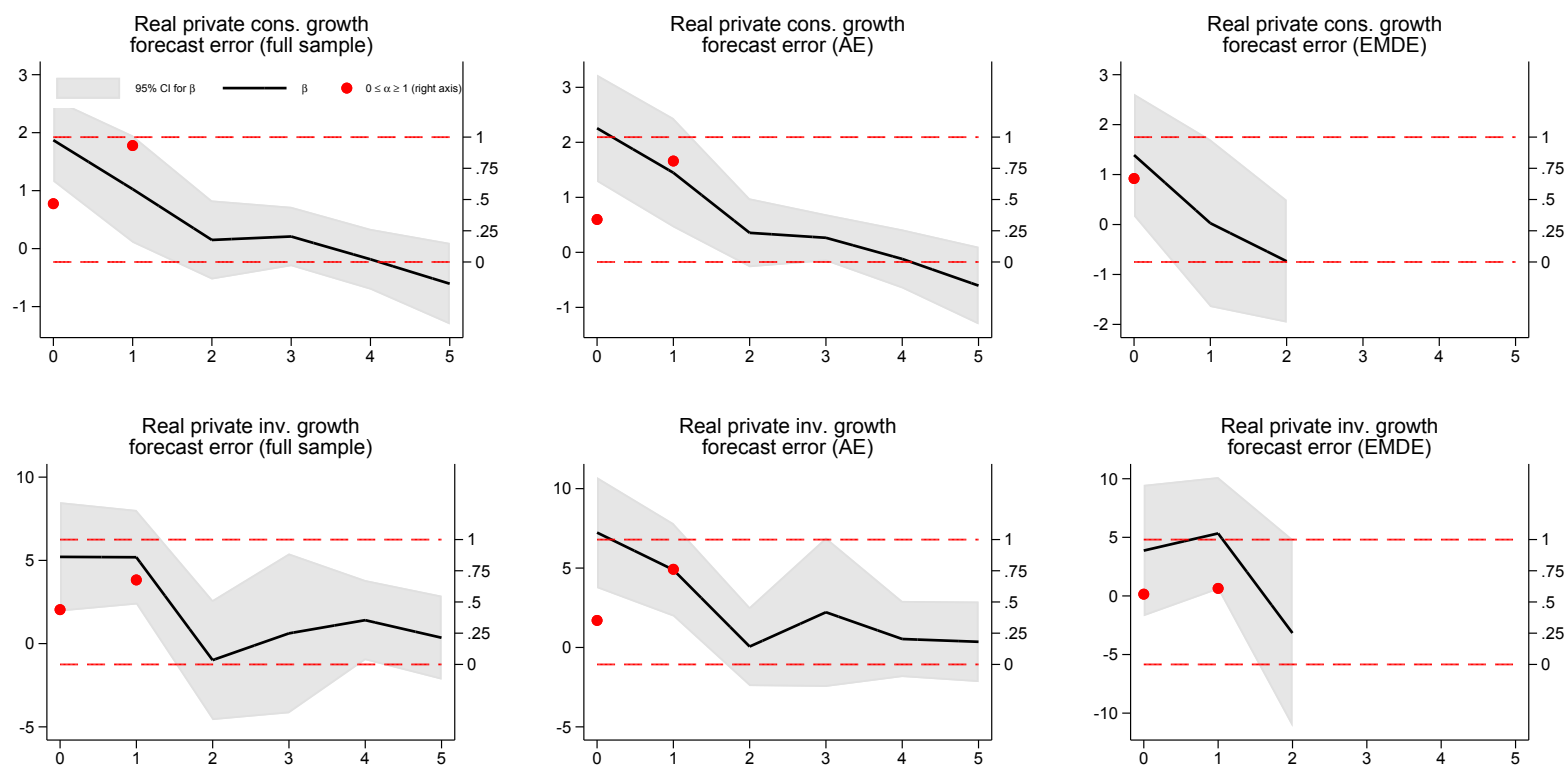

Source: Authors' calculations.

Notes: The responses for EMDE are calculated on a shorter time span due to data limitations. The value for $\alpha$ is shown only when significant.

The results suggest that that the effects of forecast revision of long-term potential output growth are generally linear. The results in column 5 for real private consumption growth, however, show a small positive and significant coefficient for the time difference term of the revision of output growth forecast. This suggests that in presence of large revisions to potential output growth forecast, private economic agents increase their consumption to a larger extent before the WEO Fall publication, as indicated by a larger $\alpha$ coefficient.

We now move to check how results would change when adding control variables. The selection of the variables relies on consumption theory as well as data availability. ${ }^{25}$ In what follows, we provide a rationale for the inclusion of each variable and discuss its expected effect. $D_{t}^{x}$ in equation (27) includes terms of trade, real public consumption growth (or real public investment growth), real short-term interest rate, and inflation. A terms of trade improvement has a direct effect on income and, if such increase in income is temporary (permanent), both the permanent-income hypothesis and the life-cycle hypothesis ( $\mathrm{LCH}$ ) predict that it should be saved (consumed). At the same time, since imported goods cover a larger share than exported goods in the composition of consumption, higher terms of trade reduce the consumption deflator, negatively affecting real consumption. In sum, the overall effect of terms of trade is ambiguous.

${ }^{25}$ For a review of consumption theories and determinants see Grigoli et al. (2014). 
Table 4: Interactions

\begin{tabular}{|c|c|c|c|c|c|c|}
\hline & $\begin{array}{l}\text { Dep: real } \\
\text { PC } \\
\text { growth } \\
\text { forecast } \\
\text { error }\end{array}$ & $\begin{array}{l}\text { Dep: real } \\
\text { PI } \\
\text { growth } \\
\text { forecast } \\
\text { error }\end{array}$ & $\begin{array}{l}\text { Dep: real } \\
\text { PC } \\
\text { growth } \\
\text { forecast } \\
\text { error }\end{array}$ & $\begin{array}{l}\text { Dep: real } \\
\text { PI } \\
\text { growth } \\
\text { forecast } \\
\text { error }\end{array}$ & $\begin{array}{l}\text { Dep: real } \\
\text { PC } \\
\text { growth } \\
\text { forecast } \\
\text { error }\end{array}$ & $\begin{array}{l}\text { Dep: real } \\
\text { PI } \\
\text { growth } \\
\text { forecast } \\
\text { error }\end{array}$ \\
\hline$R_{t+1}^{4}-R_{t}^{4}$ & $\begin{array}{c}1.102^{* * *} \\
(0.393)\end{array}$ & $\begin{array}{c}3.116^{* * *} \\
(1.072)\end{array}$ & $\begin{array}{c}0.710^{* *} \\
(0.342)\end{array}$ & $\begin{array}{l}2.484^{*} \\
(1.341)\end{array}$ & $\begin{array}{c}0.868^{* * *} \\
(0.229)\end{array}$ & $\begin{array}{c}2.358^{* * *} \\
(0.705)\end{array}$ \\
\hline$=0$ & $\begin{array}{c}2.498^{* * * *} \\
(0.724)\end{array}$ & $\begin{array}{c}8.546 * * * \\
(2.329)\end{array}$ & $\begin{array}{l}1.167^{* *} \\
(0.526)\end{array}$ & $\begin{array}{l}3.375 \\
(3.382)\end{array}$ & $\begin{array}{c}1.817^{* * * *} \\
(0.356)\end{array}$ & $\begin{array}{c}5.252^{* * *} \\
(1.855)\end{array}$ \\
\hline$D^{a f t e r G F C} *\left(R_{t+1}^{4}-R_{t}^{4}\right)$ & $\begin{array}{l}-0.324 \\
(0.485)\end{array}$ & $\begin{array}{l}-1.139 \\
(1.324)\end{array}$ & & & & \\
\hline$D^{a f t e r G F C} * R_{t}^{4}$ & $\begin{array}{l}-0.873 \\
(0.843)\end{array}$ & $\begin{array}{l}-4.569 \\
(3.055)\end{array}$ & & & & \\
\hline$D^{\text {afterGFC }}$ & $\begin{array}{l}-0.130 \\
(0.526)\end{array}$ & $\begin{array}{c}4.251 \\
(2.697)\end{array}$ & & & & \\
\hline$D^{\text {pessimism }} *\left(R_{t+1}^{4}-R_{t}^{4}\right)$ & & & $\begin{array}{c}0.234 \\
(0.433)\end{array}$ & $\begin{array}{c}-0.221 \\
(1.616)\end{array}$ & & \\
\hline$D^{\text {pessimism }} *\left(R_{t}^{4}\right)$ & & & $\begin{array}{c}1.134 \\
(0.775)\end{array}$ & $\begin{array}{c}3.053 \\
(3.564)\end{array}$ & & \\
\hline$D^{\text {pessimism }}$ & & & $\begin{array}{c}0.042 \\
(0.249)\end{array}$ & $\begin{array}{l}-0.205 \\
(0.861)\end{array}$ & & \\
\hline$\left(R_{t+1}^{4}-R_{t}^{4}\right)^{2}$ & & & & & $\begin{array}{l}0.186^{*} \\
(0.101)\end{array}$ & $\begin{array}{l}-0.577 \\
(0.478)\end{array}$ \\
\hline$\left(R_{t}^{4}\right)^{2}$ & & & & & $\begin{array}{l}-0.238 \\
(0.227)\end{array}$ & $\begin{array}{c}0.286 \\
(0.410)\end{array}$ \\
\hline Constant & $\begin{array}{l}-0.542^{*} \\
(0.290)\end{array}$ & $\begin{array}{l}-4.860^{*} \\
(2.448)\end{array}$ & $\begin{array}{l}-0.399 \\
(0.305)\end{array}$ & $\begin{array}{l}-4.176 \\
(2.587)\end{array}$ & $\begin{array}{c}-0.668^{* *} \\
(0.317)\end{array}$ & $\begin{array}{l}-4.639^{*} \\
(2.560)\end{array}$ \\
\hline Observations & 782 & 566 & 782 & 566 & 782 & 566 \\
\hline$R^{2}$ & 0.202 & 0.197 & 0.203 & 0.193 & 0.205 & 0.195 \\
\hline Countries & 89 & 83 & 89 & 83 & 89 & 83 \\
\hline$\alpha \mathrm{w} / \mathrm{o}$ interaction & 0.441 & 0.365 & 0.608 & & 0.478 & 0.449 \\
\hline$\beta \mathrm{w} / \mathrm{o}$ interaction & 2.498 & 8.546 & 1.167 & & 1.817 & 5.252 \\
\hline$\alpha \mathrm{w} /$ interaction & 0.441 & 0.365 & 0.608 & & 0.580 & 0.449 \\
\hline$\beta \mathrm{w} /$ interaction & 2.498 & 8.546 & 1.167 & & 1.817 & 5.252 \\
\hline
\end{tabular}

With respect to public consumption (and more generally fiscal policy), the Ricardian-equivalence hypothesis predicts that any increase should be fully offset by lower private consumption (Barro, 1974; Seater, 1993). While a full offset is empirically unlikely, to the extent that public and private consumption are substitutes, some offsetting should occur. In the unlikely case in which these turn out to be complements in consumer utility, a positive effect can be observed (Lopez et al., 2000).

Real interest rates are used here to capture the effects of monetary policy or more broadly credit conditions. If the consumer is a net creditor, substitution and human-wealth effects of a higher rate of return on consumption are negative, while the income effect is positive. If the consumer is a net debtor, the income effect turns negative. All in all, the combined net effect is ambiguous. Higher inflation lowers consumption as it makes current prices of consumer goods higher relative to past prices. At the same time, to the extent that current inflation proxies macroeconomic instability, it would lead to precautionary saving reducing consumption. Also, if higher current inflation signals increases in expected future inflation, this lowers the ex-ante real interest rate, inducing intertemporal substitution, income, and human-wealth effects that, on balance, imply an overall ambiguous effect on consumption.

$S_{t}$ in equation (27) in includes some demographics variables, such as old-age dependency ratio and 
the share of urban population. The LCH predicts a hump-shaped pattern of saving along the life cycle. Thus, an increase in the old-age dependency ratio should bring about an increase in consumption. Regarding the share of urban population, theory suggests that the "city lights" are associated with consumption opportunities for city dwellers compared to the rural population. Also, farmers are likely to face larger income uncertainty and less insurance and credit opportunities than urban dwellers, leading to lower consumption in rural areas. However, farmers are generally poorer than city dwellers, therefore a move of urban population towards rural areas should be associated with higher consumption. Hence, urbanization affects consumption ambiguously. Given that demographic variables are not subject to large unforeseen changes, the lack of forecast to construct a measure of the forecast error (and the use of the observed value instead) should not affect the results.

Table 5 presents the results of the S-GMM estimations including the control variables. Column 1 and 2 include the inflation forecast error, as well as the lagged dependent variable. Columns 3 and 4 add the terms of trade forecast error. In columns 5 and 6 we include the public counterpart of real consumption growth and real investment growth, respectively. Columns 7 and 8 include the forecast error for the short-term real interest rate. Finally, columns 9 and 10 include the oldage dependency ratio and the share of urban population. All control variables, except the demographic ones and terms of trade forecast error, are treated as endogenous.

The results suggest that the impact of revisions to potential output growth forecast is generally robust to the inclusion of the control variables. The lag of real private investment growth is also significant, suggesting some persistence. In the results for real private consumption growth, inflation forecast error turns out negative and significant. Finally, the results for real private investment growth indicate that a terms of trade improvement is reflected in higher investment. Notably, neither the variables proxying changes in fiscal policy or credit conditions turn out significant, possibly because of the delays in affecting macroeconomic variables. ${ }^{26}$ The coefficient $\alpha$, when significant, is about 0.3 (ranges between 0.4 and 0.5 ) for real private consumption (investment) growth, consistent with the baseline specification. $\beta$ is always significant, and ranges between 1.7 and 2.2 (5.1 and 7.1) for real private consumption (investment) growth. These magnitudes are very similar to the ones of the baseline estimations. The coefficients indeed imply that a $0.1 \mathrm{pp}$ downward revision in the potential output growth forecast is associated with a 0.17 to 0.22 (0.51 to 0.71 ) percent reduction in private consumption (investment) growth. For the average country with a share of private consumption (investment) to GDP of 65 (16) percent, this would bring about a reduction in GDP growth by 0.11 to 0.14 (0.08 to 0.11$)$ percent. $^{27}$

\subsection{Robustness}

To ensure that the positive effect of expectations on aggregate demand is not unique to the timing of the revision of the potential output growth forecast, the WEO dataset, or the use of a specific estimator, we perform a battery of robustness tests. Table 6 presents the results of the baseline specification using varying lags of the revisions to potential output growth forecast in columns 1

\footnotetext{
${ }^{26}$ In order to have a significant effect, we would need to observe deviations in private consumption and investment growth rates with respect to their forecasted growth rates in the last three months months of the year, i.e. after the Fall WEO publication.

${ }^{27}$ One should note that while at 5 percent significance level the identification assumptions are valid, at 10 percent significance level the test for second-order autocorrelation in the residuals rejects the null of no autocorrelation in some specifications for real private consumption growth, and the Hansen $J$-test for over-identifying restrictions rejects the null of instruments validity in some specifications for real private investment growth. Reassuringly, the results are broadly the same when the assumptions are valid.
} 
Table 5: Controls

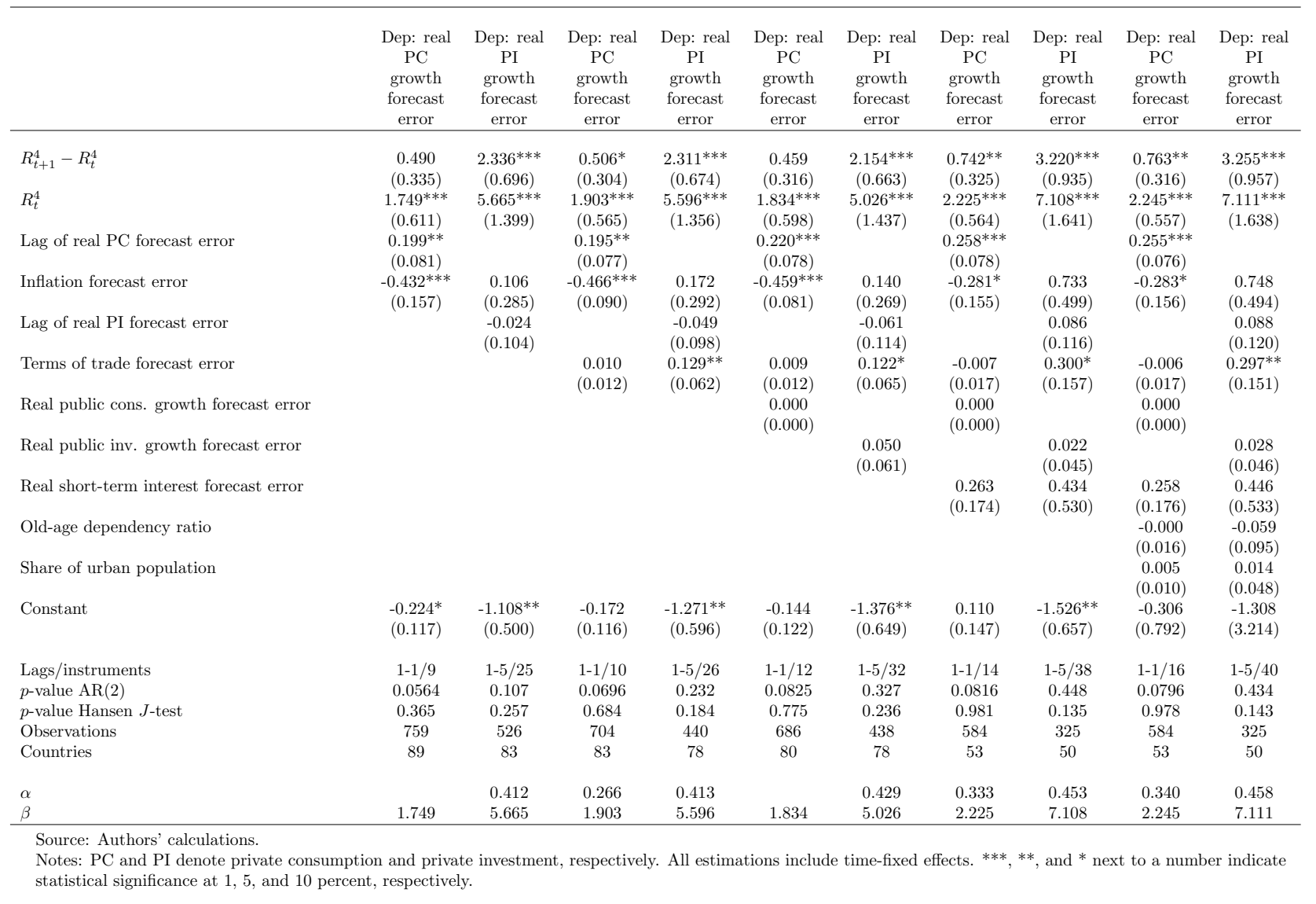

to 8 , and constructing the expectation variables with OECD data in columns 9 and $10 .{ }^{28}$

The results turn out generally robust. Constructing the revision to potential output growth forecasts comparing the latest available year in each vintage, or for one, two, and three years ahead instead of four, does not affect the results. When we use OECD data, the number of countries drops to 32 to 34 . Nevertheless, the $\beta$ coefficients turn out significant and comparable in terms of magnitude to the ones of the baseline specification. The $\alpha$ coefficient in the regression for real private investment growth is also significant and similar in size to the one in the baseline specification, but turns out insignificant in the specification for real private consumption growth. The portion of variation in the dependent variables explained by expectations is much higher in the regressions using OECD data (between 28 and 45 percent), probably because of relatively higher homogeneity of the countries in the sample.

Table 7 presents the results for the baseline specification using a different set of estimators. We start with a plain pooled OLS estimator (columns 1 and 2). Then, we allow for heterogeneous variance and auto-correlation in the residuals by employing the Feasible Generalized Least Squares (FGLS) estimator with time-fixed effect (columns 3 and 4). We also correct for cross-sectional de-

\footnotetext{
${ }^{28}$ We rely on the December edition of the OECD Economic Outlook database as its release coincides most closely with the Fall WEO. Data is available from 1996 to 2016, but forecasts of potential output growth are available only for the following two years. This leaves us with only one option of constructing the revision of potential output growth forecast for the following year.
} 
Table 6: Robustness Checks

\begin{tabular}{|c|c|c|c|c|c|c|c|c|c|c|}
\hline & $\begin{array}{l}\text { Dep: real } \\
\text { PC } \\
\text { growth } \\
\text { forecast } \\
\text { error } \\
\end{array}$ & $\begin{array}{l}\text { Dep: real } \\
\text { PI } \\
\text { growth } \\
\text { forecast } \\
\text { error }\end{array}$ & $\begin{array}{l}\text { Dep: real } \\
\text { PC } \\
\text { growth } \\
\text { forecast } \\
\text { error }\end{array}$ & $\begin{array}{l}\text { Dep: real } \\
\text { PI } \\
\text { growth } \\
\text { forecast } \\
\text { error }\end{array}$ & $\begin{array}{l}\text { Dep: real } \\
\text { PC } \\
\text { growth } \\
\text { forecast } \\
\text { error }\end{array}$ & $\begin{array}{l}\text { Dep: real } \\
\text { PI } \\
\text { growth } \\
\text { forecast } \\
\text { error } \\
\end{array}$ & $\begin{array}{l}\text { Dep: real } \\
\text { PC } \\
\text { growth } \\
\text { forecast } \\
\text { error } \\
\end{array}$ & $\begin{array}{l}\text { Dep: real } \\
\text { PI } \\
\text { growth } \\
\text { forecast } \\
\text { error }\end{array}$ & $\begin{array}{l}\text { Dep: real } \\
\text { PC } \\
\text { growth } \\
\text { forecast } \\
\text { error } \\
\end{array}$ & $\begin{array}{l}\text { Dep: real } \\
\text { PI } \\
\text { growth } \\
\text { forecast } \\
\text { error } \\
\end{array}$ \\
\hline$R_{t+1}^{5}-R_{t}^{4}$ & $\begin{array}{c}0.659^{* *} \\
(0.272)\end{array}$ & $\begin{array}{c}2.470^{* * *} \\
(0.812)\end{array}$ & & & & & & & & \\
\hline$R_{t}^{4}$ & $\begin{array}{c}1.420^{* * *} \\
(0.455)\end{array}$ & $\begin{array}{c}5.452^{* * *} \\
(1.865)\end{array}$ & & & & & & & & \\
\hline$R_{t+1}^{3}-R_{t}^{3}$ & & & $\begin{array}{c}0.808^{* * *} \\
(0.229)\end{array}$ & $\begin{array}{c}2.199^{* * *} \\
(0.606)\end{array}$ & & & & & & \\
\hline$R_{t}^{3}$ & & & $\begin{array}{c}2.026^{* * *} \\
(0.299)\end{array}$ & $\begin{array}{c}6.091^{* * *} \\
(1.388)\end{array}$ & & & & & & \\
\hline$R_{t+1}^{2}-R_{t}^{2}$ & & & & & $\begin{array}{c}1.042^{* * *} \\
(0.259)\end{array}$ & $2.320 * * *$ & & & & \\
\hline$R_{t}^{2}$ & & & & & $\begin{array}{c}2.147^{* * *} \\
(0.312)\end{array}$ & $\begin{array}{c}6.635^{* * *} \\
(1.471)\end{array}$ & & & & \\
\hline$R_{t+1}^{1}-R_{t}^{1}$ & & & & & & & $\begin{array}{c}0.979^{* * *} \\
(0.178)\end{array}$ & $\begin{array}{c}2.687^{* * *} \\
(0.789)\end{array}$ & & \\
\hline$R_{t}^{1}$ & & & & & & & $\begin{array}{c}1.927^{* * * *} \\
(0.335)\end{array}$ & $\begin{array}{c}6.048^{* * * *} \\
(1.157)\end{array}$ & & \\
\hline$R_{t+1}^{1}-R_{t}^{1}($ OECD data $)$ & & & & & & & & & $\begin{array}{c}0.286 \\
(0.195)\end{array}$ & $\begin{array}{c}3.261^{* * *} \\
(0.900)\end{array}$ \\
\hline$R_{t}^{1}$ (OECD data) & & & & & & & & & $\begin{array}{c}1.653^{* * *} \\
(0.280)\end{array}$ & $\begin{array}{c}7.356^{* * *} \\
(1.217)\end{array}$ \\
\hline Constant & $\begin{array}{c}-0.463 \\
(0.291)\end{array}$ & $\begin{array}{c}-4.897^{*} \\
(2.511)\end{array}$ & $\begin{array}{c}-0.522^{*} \\
(0.263)\end{array}$ & $\begin{array}{c}-4.884^{*} \\
(2.528)\end{array}$ & $\begin{array}{c}-0.571^{* *} \\
(0.266)\end{array}$ & $\begin{array}{l}-4.771^{*} \\
(2.561)\end{array}$ & $\begin{array}{c}-0.431 \\
(0.267)\end{array}$ & $\begin{array}{l}-4.993^{*} \\
(2.775)\end{array}$ & $\begin{array}{l}0.439^{*} \\
(0.257)\end{array}$ & $\begin{array}{c}0.438 \\
(0.971)\end{array}$ \\
\hline Observations & 782 & 566 & 782 & 566 & 782 & 566 & 782 & 566 & 484 & \\
\hline$R^{2}$ & 0.171 & 0.185 & 0.218 & 0.206 & 0.238 & 0.228 & 0.269 & 0.234 & 0.449 & 0.376 \\
\hline Countries & 89 & 83 & 89 & 83 & 89 & 83 & 89 & 83 & 34 & 32 \\
\hline$\alpha$ & 0.464 & 0.453 & 0.399 & 0.361 & 0.485 & 0.350 & 0.508 & 0.444 & & 0.443 \\
\hline$\beta$ & 1.420 & 5.452 & 2.026 & 6.091 & 2.147 & 6.635 & 1.927 & 6.048 & 1.653 & 7.356 \\
\hline
\end{tabular}

Source: Authors' calculations.

Notes: PC and PI denote private consumption and private investment, respectively. All estimations include country and time-fixed effects. $* * *, * *$, and

* next to a number indicate statistical significance at 1,5 , and 10 percent, respectively.

pendence with a Panel Corrected Standard Error (PCSE) estimator with time-fixed effect (columns 5 and 6). To address endogeneity, we employ the 2-Stage Least Squares (2SLS) estimator with time and country-fixed effects, where we instrument the endogenous variables with their own lags (columns 7 and 8), and the S-GMM with country- and time-fixed effects (columns 9 and 10).

The results suggest that the positive impact of the revisions in potential output growth forecast is robust across alternative estimation techniques. Interestingly, not only the significance of the effect is pervasive, but also the sizes of the $\alpha$ and $\beta$ coefficients are strikingly similar across estimators, conferring confidence in the estimation presented as the baseline specification.

\section{Conclusions}

Changes in expectations about future economic activity have been often proposed as an avenue to explain short-term aggregate demand fluctuations. Regardless of whether the perturbations are due to swings in beliefs (including rational but wrong) or fundamentals, they may put in motion mechanisms that move the economy onto a new (better or worse) equilibrium. In this paper, we propose a simple theoretical model with Keynesian features consistent with this view and we empirically test whether expectations about future economic prospects (turning more optimistic or 
Table 7: Alternative Estimators

\begin{tabular}{|c|c|c|c|c|c|c|c|c|c|c|}
\hline & $\begin{array}{l}\text { Dep: real } \\
\text { PC } \\
\text { growth } \\
\text { forecast } \\
\text { error } \\
\text { Pooled }\end{array}$ & $\begin{array}{c}\text { Dep: real } \\
\text { PI } \\
\text { growth } \\
\text { forecast } \\
\text { error } \\
\text { Pooled }\end{array}$ & $\begin{array}{l}\text { Dep: real } \\
\text { PC } \\
\text { growth } \\
\text { forecast } \\
\text { error } \\
\text { FGLS }\end{array}$ & $\begin{array}{l}\text { Dep: real } \\
\text { PI } \\
\text { growth } \\
\text { forecast } \\
\text { error } \\
\text { FGLS }\end{array}$ & $\begin{array}{l}\text { Dep: real } \\
\text { PC } \\
\text { growth } \\
\text { forecast } \\
\text { error } \\
\text { PCSE }\end{array}$ & $\begin{array}{c}\text { Dep: real } \\
\text { PI } \\
\text { growth } \\
\text { forecast } \\
\text { error } \\
\text { PCSE }\end{array}$ & $\begin{array}{l}\text { Dep: real } \\
\text { PC } \\
\text { growth } \\
\text { forecast } \\
\text { error } \\
\text { 2SLS }\end{array}$ & $\begin{array}{c}\text { Dep: real } \\
\text { PI } \\
\text { growth } \\
\text { forecast } \\
\text { error } \\
\text { 2SLS }\end{array}$ & $\begin{array}{l}\text { Dep: real } \\
\text { PC } \\
\text { growth } \\
\text { forecast } \\
\text { error } \\
\text { S-GMM }\end{array}$ & $\begin{array}{c}\text { Dep: real } \\
\text { PI } \\
\text { growth } \\
\text { forecast } \\
\text { error } \\
\text { S-GMM }\end{array}$ \\
\hline & OLS & OLS & & & & & & & & \\
\hline$R_{t+1}^{4}-R_{t}^{4}$ & $\begin{array}{c}0.955^{* * *} \\
(0.264)\end{array}$ & $\begin{array}{c}3.174^{* * *} \\
(0.900)\end{array}$ & $\begin{array}{c}0.456^{* * *} \\
(0.143)\end{array}$ & $\begin{array}{c}2.547^{* * *} \\
(0.510)\end{array}$ & $\begin{array}{c}0.805^{* * *} \\
(0.273)\end{array}$ & $\begin{array}{c}3.053^{* * *} \\
(0.884)\end{array}$ & $\begin{array}{c}0.707^{* * *} \\
(0.253)\end{array}$ & $\begin{array}{c}1.960^{* *} \\
(0.876)\end{array}$ & $\begin{array}{c}0.887^{* *} \\
(0.388)\end{array}$ & $\begin{array}{c}2.672^{* * *} \\
(0.856)\end{array}$ \\
\hline$R_{t}^{4}$ & $\begin{array}{c}2.354^{* * *} \\
(0.381)\end{array}$ & $\begin{array}{c}6.746^{* * *} \\
(1.142)\end{array}$ & $\begin{array}{c}1.623^{* * *} \\
(0.209)\end{array}$ & $\begin{array}{c}5.567^{* * * *} \\
(0.736)\end{array}$ & $\begin{array}{c}1.873^{* * *} \\
(0.364)\end{array}$ & $\begin{array}{c}6.173^{* * *} \\
(1.297)\end{array}$ & $\begin{array}{c}1.872^{\text {**** }}(0.330)\end{array}$ & $\begin{array}{c}4.689^{* * * *} \\
(1.433)\end{array}$ & $\begin{array}{c}2.222^{* * * *} \\
(0.654)\end{array}$ & $\begin{array}{c}5.895^{* * *} \\
(1.802)\end{array}$ \\
\hline Lag of real PC forecast error & & & & & & & & & $\begin{array}{c}0.195^{* * *} \\
(0.075)\end{array}$ & \\
\hline Lag of real PI forecast error & & & & & & & & & & $\begin{array}{c}-0.012 \\
(0.131)\end{array}$ \\
\hline Constant & $\begin{array}{c}-0.248^{* *} \\
(0.104)\end{array}$ & $\begin{array}{c}-1.040^{* *} \\
(0.437)\end{array}$ & $\begin{array}{c}-1.268^{* * *} \\
(0.288)\end{array}$ & $\begin{array}{c}-5.937 * * * \\
(1.257)\end{array}$ & $\begin{array}{c}-0.291 \\
(0.343)\end{array}$ & $\begin{array}{c}-5.684^{* * *} \\
(1.366)\end{array}$ & $\begin{array}{c}0.743^{* *} \\
(0.343)\end{array}$ & $\begin{array}{c}0.766 \\
(1.186)\end{array}$ & $\begin{array}{l}-0.132 \\
(0.113)\end{array}$ & $\begin{array}{c}-1.047^{* *} \\
(0.463)\end{array}$ \\
\hline$p$-value $\operatorname{AR}(2)$ & & & & & & & & & 0.053 & 0.118 \\
\hline$p$-value Hansen $J$-test & & & & & & & & & 0.622 & 0.121 \\
\hline Observations & 782 & 566 & 774 & 557 & 782 & 566 & 644 & 416 & 759 & 526 \\
\hline Countries & 89 & 83 & 81 & 74 & 89 & 83 & 60 & 56 & 89 & 83 \\
\hline$\alpha$ & & 0.412 & 0.266 & 0.413 & & 0.429 & 0.333 & 0.453 & 0.340 & 0.458 \\
\hline$\beta$ & 1.749 & 5.665 & 1.903 & 5.596 & 1.834 & 5.026 & 2.225 & 7.108 & 2.245 & 7.111 \\
\hline
\end{tabular}

Source: Authors' calculations.

Notes: PC and PI denote private consumption and private investment, respectively. FGLS, PCSE, 2SLS estimations include country- and time-fixed effects, S-GMM estimations include time-fixed effects. ${ }^{* *},{ }^{* *}$, and ${ }^{*}$ next to a number indicate statistical significance at 1,5 , and 10 percent, respectively.

pessimistic) have a role in determining short-term fluctuations in private consumption and investment.

The results from the theoretical model suggest that changes in expected long-term income have self-fulling effects in the direction of the change in expectations. Concretely, if agents expect longterm output growth to be high (low), short-term consumption, investment, and output increase (fall) in the short-term, and unemployment falls (increases). Relying on a dataset of actual data and forecasts for 89 countries over the 1990-2022 period, we find supportive evidence for the theoretical conclusions. Private economic agents learn from different sources of information about the future potential output growth of the economy and adjust their consumption and investment levels accordingly over the two years following the shock in expectations. Specifically, $0.1 \mathrm{pp}$ upward revision in the potential output growth forecast is associated with a 0.19 to 0.25 (0.39 to 0.72 ) percent increase in private consumption (investment) growth. For the average country with a share of private consumption (investment) to GDP of 65 (16) percent, this would bring about an acceleration in GDP growth by 0.09 to 0.16 (0.06 to 0.11$)$ percent.

We also find that the estimated effects are generally linear and robust to different specifications and estimators. Despite changes in expectations became more frequent, negatively skewed, and volatile in the aftermath of the GFC, the estimated impact is not statistically different with respect to the period preceding the GFC. Similarly, pessimistic and optimistic expectations do not present a differential impact on private consumption nor private investment, and large changes in expectations induce proportional changes in demand.

These findings have some policy implications. If changes in expectations about future economic conditions cause short-term fluctuations in aggregate demand, economic policy could aim at curbing such fluctuations when these place the economy in an inferior equilibrium or generate undesired instability. While both policymakers and economic agents are subject to the same (or sim- 
ilar) restrictions in accessing information about future economic activity, credible commitments remain a valuable tool. To the extent that institutions are credible, a commitment to policy intervention to stabilize undesired fluctuations could act on the expectation formation mechanisms by deterring economic agents from moving the economy to an inferior equilibrium. This line of analysis, however, is left for future research. 


\section{References}

Acharya, Sushant, Jess Benhabib, and Zhen Huo (2017). "The Anatomy of Sentiment-Driven Fluctuations". In: National Bureau of Economic Research Working Paper No. 23126.

Akerlof, George A and Robert J Shiller (2010). Animal Spirits: How Human Psychology Drives the Economy, and Why It Matters for Global Capitalism. Princeton University Press.

Arellano, Manuel and Stephen Bond (1991). "Some Tests of Specification for Panel Data: Monte Carlo Evidence and an Application to Employment Equations". In: The Review of Economic Studies 58.2, pp. 277-297.

Banerjee, Abhijit V (1992). "A Simple Model of Herd Behavior". In: The Quarterly Journal of Economics 107.3, pp. 797-817.

Barro, Robert J (1974). "Are Government Bonds Net Wealth?" In: Journal of Political Economy 82.6, pp. $1095-1117$.

Barsky, Robert B and Eric R Sims (2012). "Information, Animal Spirits, and the Meaning of Innovations in Consumer Confidence". In: The American Economic Review 102.4, pp. 1343-1377.

Beaudry, Paul, Martial Dupaigne, and Franck Portier (2011). "Modeling News-Driven International Business Cycles". In: Review of Economic Dynamics 14.1, pp. 72-91.

Beaudry, Paul and Bernd Lucke (2010). "Letting Different Views About Business Cycles Compete". In: NBER Macroeconomics Annual 24.1, pp. 413-456.

Beaudry, Paul and Franck Portier (2004). "An Exploration into Pigou's Theory of Cycles". In: Journal of Monetary Economics 51.6, pp. 1183-1216.

- (2006). "Stock Prices, News, and Economic Fluctuations". In: The American Economic Review 96.4, pp. 1293-1307.

- (2014). "News-Driven Business Cycles: Insights and Challenges". In: Journal of Economic Literature 52.4, pp. 993-1074.

Benhabib, Jess, Xuewen Liu, and Pengfei Wang (2016). "Sentiments, Financial Markets, and Macroeconomic Fluctuations". In: Journal of Financial Economics 120.2, pp. 420-443.

Benigno, Pierpaolo (2015). "New-Keynesian Economics: An AS-AD View". In: Research in Economics 69.4 , pp. 503-524.

Blanchard, Olivier J and Nobuhiro Kiyotaki (1987). "Monopolistic Competition and the Effects of Aggregate Demand". In: The American Economic Review, pp. 647-666.

Blanchard, Olivier J, Jean-Paul L'Huillier, and Guido Lorenzoni (2013). "News, Noise, and Fluctuations: An Empirical Exploration". In: The American Economic Review 103.7, pp. 30453070.

Blanchard, Olivier J, Guido Lorenzoni, and Jean-Paul L'Huillier (2017). "Short-Run Effects of Lower Productivity Growth. A Twist on the Secular Stagnation Hypothesis". In: Journal of Policy Modeling 39.4, pp. 639-649.

Blundell, Richard and Stephen Bond (1998). "Initial Conditions and Moment Restrictions in Dynamic Panel Data Models". In: Journal of Econometrics 87.1, pp. 115-143.

Cass, David and Karl Shell (1983). "Do Sunspots Matter?" In: Journal of Political Economy 91.2, pp. $193-227$.

Chauvet, Marcelle and Jang-Ting Guo (2003). "Sunspots, Animal Spirits, and Economic Fluctuations". In: Macroeconomic Dynamics 7.01, pp. 140-169.

Choy, Keen Meng, Kenneth Leong, and Anthony S Tay (2006). "Non-Fundamental Expectations and Economic Fluctuations: Evidence from Professional Forecasts". In: Journal of Macroeconomics 28.2, pp. 446-460.

Cochrane, John H (1994). "Shocks". In: Carnegie-Rochester Conference Series on Public Policy. Vol. 41. Elsevier, pp. 295-364.

Cooper, Russell and Andrew John (1988). "Coordinating Coordination Failures in Keynesian Models". In: The Quarterly Journal of Economics 103.3, pp. 441-463. 
De Grauwe, Paul and Yuemei Ji (2016). "Animal Spirits and the International Transmission of Business Cycles". In: CESifo Area Conference on Macro, Money 83 Interational Finance.

De Resende, Carlos (2014). "An Assessment of IMF Medium-Term Forecasts of GDP Growth". In: IEO Background Paper No. BP/14/01 (Washington: Independent Evaluation Office of the IMF).

Friedman, Milton (1957). "The Permanent Income Hypothesis". In: A Theory of the Consumption Function. Princeton University Press, pp. 20-37.

Godley, W and M Lavoie (2007). Monetary Economics: An Integrated Approach to Credit, Money, Production and Wealth, Basingstone. Palgrave Macmillan.

Grigoli, Francesco, Alexander Herman, and Klaus Schmidt-Hebbel (2014). "World Saving". In: International Monetary Fund Working Paper 16/160.

Grisse, Christian (2009). "Are Expectations About Economic Activity Self-Fulfilling? An Empirical Test". In: Mimeo. Federal Reserve Bank of New York.

Hall, Robert E (1978). "Stochastic Implications of the Life Cycle-Permanent Income Hypothesis: Theory and Evidence". In: Journal of Political Economy 86.6, pp. 971-987.

Jaimovich, Nir and Sergio Rebelo (2009). "Can News About the Future Drive the Business Cycle?" In: The American Economic Review 99.4, pp. 1097-1118.

Jordà, Òscar (2005). "Estimation and Inference of Impulse Responses by Local Projections". In: The American Economic Review 95.1, pp. 161-182.

Keynes, John Maynard (1936). General Theory of Employment, Interest and Money. London: Macmillan.

Lopez, J Humberto, Klaus Schmidt-Hebbel, and Luis Servén (2000). "How Effective Is Fiscal Policy in Raising National Saving?" In: Review of Economics and Statistics 82.2, pp. 226-238.

Lorenzoni, Guido (2009). "A Theory of Demand Shocks". In: The American Economic Review 99.5, pp. 2050-2084.

Martin, Felix (2015). Money: The Unauthorized Biography-from Coinage to Cryptocurrencies. Vintage.

Matsusaka, John G and Argia M Sbordone (1995). "Consumer Confidence and Economic Fluctuations". In: Economic Inquiry 33.2, pp. 296-318.

Oh, Seonghwan and Michael Waldman (1990). "The Macroeconomic Effects of False Announcements". In: The Quarterly Journal of Economics 105.4, pp. 1017-1034.

- (2005). "The Index of Leading Economic Indicators as a Source of Expectational Shocks". In: Eastern Economic Journal 31.1, pp. 75-95.

Rigobon, Roberto (2003). "Identification Through Heteroskedasticity". In: Review of Economics and Statistics 85.4, pp. 777-792.

Sargent, Thomas J (1987). Macroeconomic Theory-Economic Theory, Econometrics, and Mathematical Economics.

Schmitt-Grohé, Stephanie and Martin Uribe (2012). "What's News in Business Cycles". In: Econometrica 80.6, pp. 2733-2764.

Seater, John J (1993). "Ricardian Equivalence". In: Journal of Economic Literature 31.1, pp. 142190.

Sims, Eric R (2009). "Expectations Driven Business Cycles: An Empirical Evaluation". In: Unpublished manuscript. University of Notre Dame.

Weil, Philippe (1989). "Increasing Returns and Animal Spirits". In: The American Economic Review 79.4, pp. 889-894.

Windmeijer, Frank (2005). "A Finite Sample Correction for the Variance of Linear Efficient TwoStep GMM Estimators". In: Journal of Econometrics 126.1, pp. 25-51. 


\section{Appendix A. Country Groups}

Advanced Economies: Australia, Austria, Belgium, Canada, Cyprus, Czech Republic, Denmark, Estonia, Finland, France, Germany, Greece, Hong Kong, Iceland, Ireland, Israel, Italy, Japan, Latvia, Lithuania, Luxembourg, Malta, Netherlands, New Zealand, Norway, Portugal, Singapore, Slovak Republic, Slovenia, South Korea, Spain, Sweden, Switzerland, Taiwan, United Kingdom, United States.

Emerging Market and Developing Economies: Algeria, Antigua and Barbuda, Armenia, Bahamas, Barbados, Belize, Bosnia and Herzegovina, Brazil, Bulgaria, Chile, China, Colombia, Costa Rica, Croatia, Dominica, Dominican Republic, Egypt, El Salvador, Georgia, Grenada, Guatemala, Haiti, Honduras, Hungary, India, Indonesia, Jamaica, Kazakhstan, Kenya, Lebanon, Malaysia, Mauritius, Mexico, Moldova, Montserrat, Nicaragua, Pakistan, Panama, Peru, Philippines, Poland, Romania, Russia, South Africa, St. Kitts and Nevis, St. Lucia, St. Vincent and the Grenadines, Swaziland, Thailand, Togo, Turkey, Ukraine, Uruguay. 


\section{Appendix B. Data}

Table B.1 lists all variables used in the empirical analysis, along with the source and scales.

Table B.1: Data Sources

\begin{tabular}{|c|c|c|}
\hline Variable & Source & Scale \\
\hline $\begin{array}{l}\text { Real private consumption } \\
\text { growth forecast error }\end{array}$ & IMF World Economic Outlook & Percent \\
\hline $\begin{array}{l}\text { Real private investment } \\
\text { growth forecast error }\end{array}$ & IMF World Economic Outlook & Percent \\
\hline $\begin{array}{l}\text { Revision in potential } \\
\text { growth forecast }\end{array}$ & $\begin{array}{l}\text { IMF World Economic Outlook } \\
\text { and OECD Economic Outlook }\end{array}$ & Percent \\
\hline General government debt & IMF World Economic Outlook & Percent of GDP \\
\hline Inflation forecast error & IMF World Economic Outlook & Percent \\
\hline $\begin{array}{l}\text { Terms of trade forecast } \\
\text { error }\end{array}$ & IMF World Economic Outlook & Percent \\
\hline $\begin{array}{l}\text { Real public consumption } \\
\text { growth forecast error }\end{array}$ & IMF World Economic Outlook & Percent \\
\hline $\begin{array}{l}\text { Real public investment } \\
\text { growth forecast error }\end{array}$ & IMF World Economic Outlook & Percent \\
\hline $\begin{array}{l}\text { Real short-term interest } \\
\text { rate forecast error }\end{array}$ & $\begin{array}{l}\text { IMF International Financial Statistics } \\
\text { and Haver }\end{array}$ & Percent \\
\hline Old-age dependency ratio & $\begin{array}{l}\text { World Bank World Development } \\
\text { Indicators }\end{array}$ & $\begin{array}{l}\text { Percent of working-age } \\
\text { population }\end{array}$ \\
\hline Share of urban population & World Bank World Development Indicators & Percent of population \\
\hline
\end{tabular}

